\title{
Near-Zero Emissions Oxy-Combustion Flue Gas Purification - Power Plant Performance
}

\author{
Topical Report \\ July1, 2009 to June 30, 2010
}

Prepared by Foster Wheeler

For Praxair, Inc.

Principal Authors from Foster Wheeler Andrew Seltzer

Zhen Fan

March 2011

DOE Award No. DE-NT0005341

Submitting Organization (Contractor):

Praxair, Inc.

175 East Park Drive

Tonawanda, NY 14150

Contractor's Representative:

Minish Shah

Tel: 716-879-2623

Email:minish_shah@praxair.com

Subcontractor:

Foster Wheeler North America Corp.

12 Peach Tree Hill Road

Livingston, New Jersey 07039

Subcontractor's Representative:

Horst Hack

Tel: 973-535-2200

Email: horst_hack@fwc.com 


\section{Disclaimer}

"This report was prepared as an account of work sponsored by an agency of the United States Government. Neither the United States Government nor any agency thereof, nor any of their employees, makes any warranty, express or implied, or assumes any legal liability or responsibility for the accuracy, completeness, or usefulness of any information, apparatus, product, or process disclosed, or represents that its use would not infringe privately owned rights. Reference herein to any specific commercial product, process, or service by trade name, trademark, manufacturer, or otherwise does not necessarily constitute or imply its endorsement, recommendation, or favoring by the United States Government or any agency thereof. The views and opinions of authors expressed herein do not necessarily state or reflect those of the United States Government or any agency thereof." 


\section{Abstract}

A technical feasibility assessment was performed for retrofitting oxy-fuel technology to an existing power plant burning low sulfur PRB fuel and high sulfur bituminous fuel. The focus of this study was on the boiler/power generation island of a subcritical steam cycle power plant. The power plant performance in air and oxy-firing modes was estimated and modifications required for oxy-firing capabilities were identified.

A $460 \mathrm{MWe}$ (gross) reference subcritical PC power plant was modeled. The reference air-fired plant has a boiler efficiency (PRB/Bituminous) of $86.7 \% / 89.3 \%$ and a plant net efficiency of $35.8 / 36.7 \%$. Net efficiency for oxy-fuel firing including ASU/CPU duty is $25.6 \% / 26.6 \%$ (PRB/Bituminous). The oxy-fuel flue gas recirculation flow to the boiler is $68 \% / 72 \%$ (PRB/bituminous) of the flue gas (average $\mathrm{O}_{2}$ in feed gas is $27.4 \% / 26.4 \% \mathrm{v}$ (PRB/bituminous)). Maximum increase in tube wall temperature is less than $10^{\circ} \mathrm{F}$ for oxy-fuel firing.

For oxy-fuel firing, ammonia injected to the SCR was shut-off and the FGD is applied to remove SOx from the recycled primary gas stream and a portion of the SOx from the secondary stream for the high sulfur bituminous coal.

Based on CFD simulations it was determined that at the furnace outlet compared to air-firing, $\mathrm{SO}_{3} / \mathrm{SO}_{2}$ mole ratio is about the same, NOx ppmv level is about the same for PRB-firing and 2.5 times for bituminous-firing due to shutting off the OFA, and CO mole fraction is approximately double.

A conceptual level cost estimate was performed for the incremental equipment and installation cost of the oxyfuel retrofit in the boiler island and steam system. The cost of the retrofit is estimated to be approximately $81 \mathrm{M} \$$ for PRB low sulfur fuel and $84 \mathrm{M} \$$ for bituminous high sulfur fuel. 


\section{Table of Contents}

Disclaimer ...

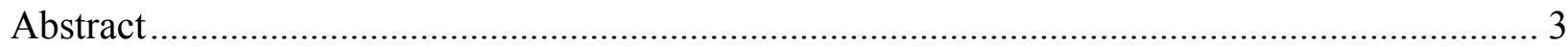

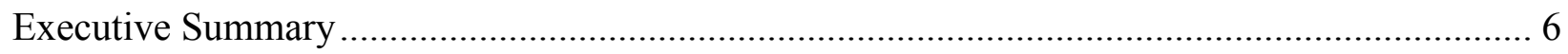

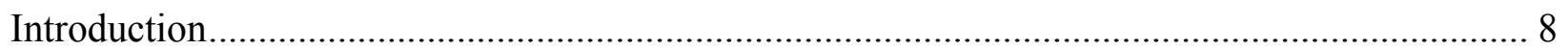

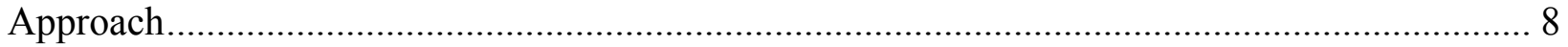

Design Basis and Assumptions ...................................................................................... 8

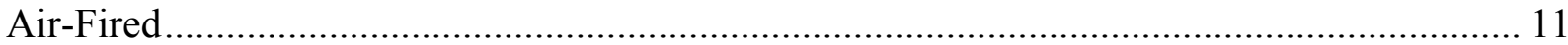

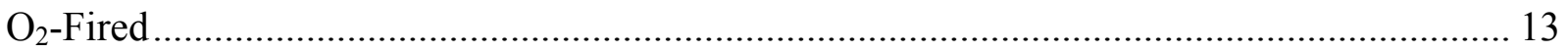

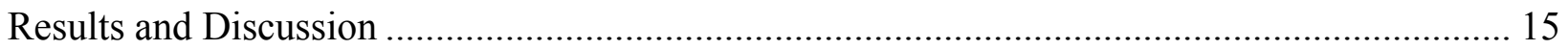

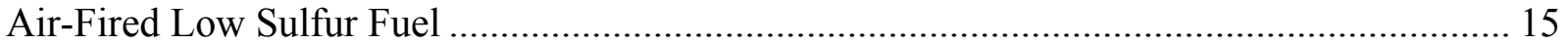

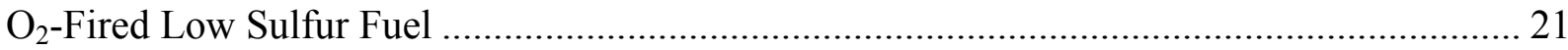

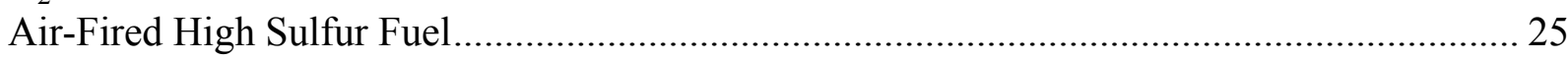

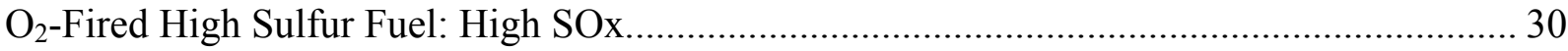

$\mathrm{O}_{2}$-Fired High Sulfur Fuel: Reduced SOx................................................................................ 31

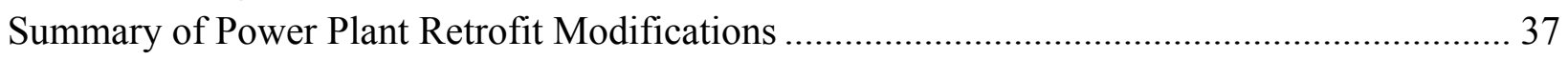

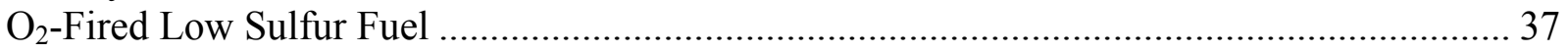

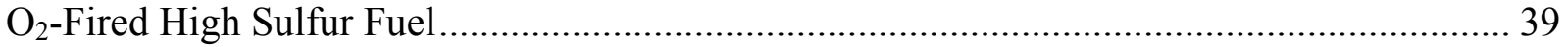

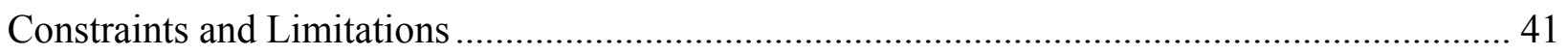

Oxyfuel Incremental Equipment Cost Estimate ………........................................................ 43

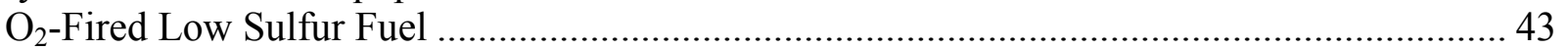

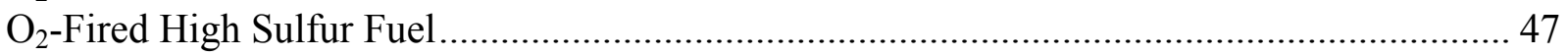

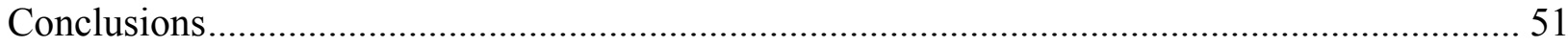

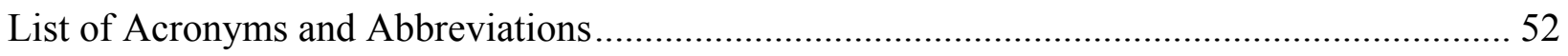

\section{List of Figures}

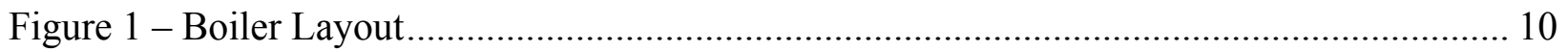

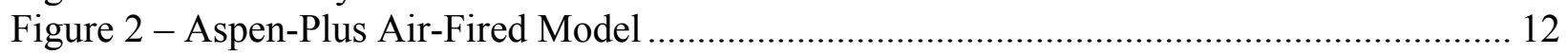

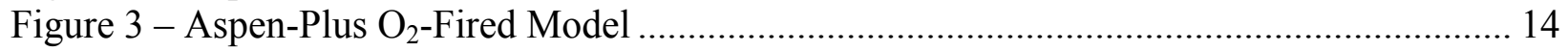

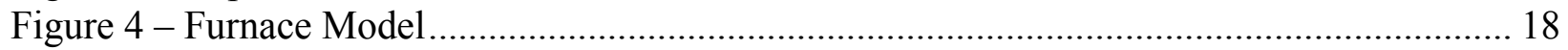

Figure 5 - Gas Temperature: Air-Fired Low Sulfur Fuel....................................................... 19

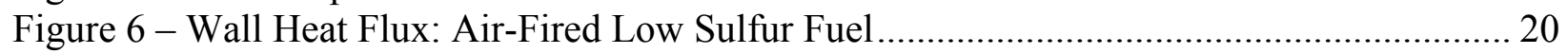

Figure 7 - Gas Temperature: $\mathrm{O}_{2}$-Fired Low Sulfur Fuel ........................................................ 22

Figure 8 - Wall Heat Flux: $\mathrm{O}_{2}$-Fired Low Sulfur Fuel............................................................. 23

Figure 9 - Gas Temperature: Air-Fired High Sulfur Fuel ........................................................ 28

Figure 10 - Wall Heat Flux: Air-Fired High Sulfur Fuel .......................................................... 29

Figure 11 - Gas Temperature: $\mathrm{O}_{2}$-Fired High Sulfur Fuel, Reduced Sox …………….................. 34

Figure 12 - Wall Heat Flux: $\mathrm{O}_{2}$-Fired High Sulfur Fuel, Reduced SOx ...................................... 35 


\section{List of Tables}

Table 1 - Summary of Performance and Emissions …………………….................................. 7

Table 2 - Site Conditions....................................................................................................... 9

Table 3 - Coal Analysis: Low Sulfur and High Sulfur Coals...................................................... 9

Table 4 - Steam Conditions ...................................................................................................... 9

Table 5 - Feed Flow Rates: Low Sulfur Fuel .................................................................... 16

Table 6 - Steam Cycle Power and Efficiency: Low Sulfur Fuel................................................. 16

Table 7 - Flue Gas Composition and Emissions: Air-Fired Low Sulfur Fuel............................... 17

Table 8 - Maximum Tube Wall Temperatures: $\mathrm{O}_{2}$-Fired Low Sulfur Fuel ................................... 24

Table 9 - Feed Flow Rates: High Sulfur Fuel ............................................................................ 26

Table 10 - Steam Cycle Power and Efficiency: High Sulfur Fuel ............................................. 26

Table 11 - Flue Gas Composition and Emissions: Air-Fired High Sulfur Fuel............................22

Table 12 - Maximum Tube Wall Temperatures: $\mathrm{O}_{2}$-Fired High Sulfur Fuel................................... 36

Table 13 - Low Sulfur Fuel $\mathrm{O}_{2}$-Fired Retrofit Incremental Cost Estimate ................................... 43

Table 14 - High Sulfur Fuel $\mathrm{O}_{2}$-Fired Retrofit Incremental Cost Estimate ……........................... 47 


\section{Executive Summary}

A technical feasibility assessment was carried out for retrofitting oxy-fuel technology to an existing power plant burning low sulfur PRB fuel and high sulfur bituminous fuel. The focus of this study was on the boiler/power generation island of a subcritical steam cycle power plant. The power plant performance in air and oxy-firing modes was estimated and modifications required for oxy-firing capabilities were identified. There appears to be no major obstacles to oxyfuel retrofitting the reference plant presented herein; however, specific constraints and limitations must be evaluated by a detailed design.

A $460 \mathrm{MWe}$ (gross) reference subcritical PC power plant was modeled using Aspen-Plus ${ }^{\circledR}$ to model the cycle and FW-FIRE to model the furnace. An air-fired simulation was run at full load. The reference air-fired plant has a boiler efficiency (PRB/Bituminous) of $86.7 \% / 89.3 \%$ and a plant net efficiency of $35.8 / 36.7 \%$.

The plant was modified for oxyfuel firing with the addition of flue gas recirculation ducts, oxygen distribution piping, steam extractions for ASU/CPU, added flue gas cooler for CPU, increased size of lower economizer in HRA, a low pressure economizer downstream of the airheater, and a quench tower after the FGD, as well as increased cooling duty. Net efficiency including ASU/CPU duty is $25.6 \% / 26.6 \%$ ( $\mathrm{PRB} /$ Bituminous). $\mathrm{CO}_{2}$ capture efficiency of the $\mathrm{CPU}$ is $99 \%$.

For oxy-fuel firing, ammonia injected to the SCR was shut-off, but the SCR catalyst remained in place for operational flexibility. Since the coal mill requires low moisture nearly SOx-free gas for proper performance and avoidance of acid corrosion, the FGD is applied to remove SOx from the recycled primary gas stream. To limit the boiler corrosive SOx concentration for the high sulfur bituminous fuel, $36 \%$ of the recycled secondary gas was also treated by the $\mathrm{FGD} . \mathrm{SO}_{2}$ in the boiler is predicted to be $500 \mathrm{ppm}$ for PRB and $4080 \mathrm{ppmv}$ and $5690 \mathrm{ppmv}$ with and without the secondary gas treatment for bituminous. Gas to the CPU was extracted before the FGD.

The flue gas recirculation flow to the boiler is $68 \% / 72 \%$ (PRB/bituminous) of the flue gas (average $\mathrm{O}_{2}$ in feed gas is $27.4 \% / 26.4 \% \mathrm{v}$ (PRB/bituminous)). Maximum increase in tube wall temperature is less than $10^{\circ} \mathrm{F}$ for oxy-fuel firing.

Based on CFD simulations it was determined that at the furnace outlet compared to air-firing, $\mathrm{SO}_{3} / \mathrm{SO}_{2}$ mole ratio is about the same, NOx ppmv level is about the same for PRB-firing and 2.5 times for bituminous-firing due to shutting off the OFA, and CO mole fraction is approximately double. Performance and emissions are summarized in Table 1.

A conceptual level cost estimate was performed for the incremental equipment and installation cost of the oxyfuel retrofit in the boiler island and steam system. The cost of the retrofit is estimated to be approximately $81 \mathrm{M} \$$ for PRB low sulfur fuel and $84 \mathrm{M} \$$ for bituminous high sulfur fuel. 
Table 1 - Summary of Performance and Emissions

\begin{tabular}{|l|c|c|c|c|c|}
\cline { 3 - 6 } \multicolumn{2}{c|}{} & \multicolumn{2}{c|}{ low S PRB } & \multicolumn{2}{c}{ High S Bit } \\
\hline Fuel Flow & & Air-fired & O2-fired & Air-fired & O2-fired \\
Air Flow & $\mathrm{klb} / \mathrm{h}$ & 449 & 452 & 331 & 334 \\
Oxygen Flow & $\mathrm{klb} / \mathrm{h}$ & 3585 & 0 & 3567 & 0 \\
Recirculated. Flue Gas & $\mathrm{klb} / \mathrm{h}$ & 0 & 725 & 0 & 712 \\
Limestone & $\%$ & $0.0 \%$ & $67.7 \%$ & $0.0 \%$ & $72.5 \%$ \\
Boiler efficiency & $\mathrm{klb} / \mathrm{h}$ & 2.14 & 1.35 & 27.2 & 17.1 \\
Gross Power & $\%$ & 86.7 & 89.4 & 89.3 & 92.4 \\
Aux. Power & $\mathrm{MWe}$ & 461 & 467 & 460 & 465 \\
ASU/CPU Power & $\mathrm{MWe}$ & 43 & 38 & 45 & 40 \\
Extra Cooling Water Power & $\mathrm{MWe}$ & & 125.9 & & 119.7 \\
Net Power & $\mathrm{MWe}$ & & 2.5 & & 2.3 \\
Net efficiency & $\mathrm{MWe}$ & 418 & 301 & 416 & 304 \\
\hline
\end{tabular}

\begin{tabular}{|r|c|c|c|c|c|c|}
\cline { 2 - 7 } \multicolumn{1}{c|}{} & \multicolumn{6}{c|}{ low Sulfur PRB } \\
\hline & \multicolumn{7}{|c|}{ Air-Fired at Stack } & \multicolumn{3}{c|}{ O2-Fired to CPU } \\
\hline & ppmv & $\mathrm{lb} / \mathrm{h}$ & $\mathrm{lb} / \mathrm{Mbtu}$ & $\mathrm{ppmv}$ & $\mathrm{lb} / \mathrm{h}$ & $\mathrm{Ib} / \mathrm{Mbtu}$ \\
\hline $\mathrm{CO}$ & 128 & 536 & 0.13 & 280 & 244 & 0.06 \\
$\mathrm{SO} 2$ & 52 & 501 & 0.13 & 465 & 928 & 0.23 \\
$\mathrm{SO} 3$ & 1.3 & 15.8 & 0.0040 & 5.8 & 14.4 & 0.0036 \\
$\mathrm{NOx}$ & 36 & 247 & 0.062 & 156 & 223 & 0.056 \\
$\mathrm{NH3}$ & 0.7 & 1.5 & 0.00037 & 0 & 0 & 0 \\
$\mathrm{HCl}$ & 0.1 & 0.8 & 0.00020 & 18 & 20.9 & 0.0052 \\
$\mathrm{PM}$ & & 49 & 0.012 & & 49 & 0.012 \\
$\mathrm{VOC}$ & 1.8 & 11.9 & 0.0030 & 1.3 & 1.8 & 0.0004 \\
& & & & & & \\
\hline & $\mathrm{ppbv}$ & $\mathrm{lb} / \mathrm{h}$ & $\mathrm{lb} /$ Tbtu & $\mathrm{ppbv}$ & $\mathrm{Ib} / \mathrm{h}$ & $\mathrm{lb} / \mathrm{Tbtu}$ \\
$\mathrm{Hg}$ & 1.7 & 0.051 & 12.8 & 10.1 & 0.063 & 15.7 \\
\hline
\end{tabular}




\begin{tabular}{|c|c|c|c|c|c|c|c|c|c|}
\hline & \multicolumn{9}{|c|}{ High Sulfur Bit. } \\
\hline & \multicolumn{3}{|c|}{ Air-Fired at Stack } & \multicolumn{6}{|c|}{ O2-Fired to CPU } \\
\hline & \multirow[b]{2}{*}{ ppmv } & \multirow[b]{2}{*}{$\mathrm{lb} / \mathrm{h}$} & \multirow[b]{2}{*}{$\mathrm{lb} / \mathrm{Mbtu}$} & \multirow[b]{2}{*}{ ppmv } & \multirow[b]{2}{*}{$\mathrm{Ib} / \mathrm{h}$} & \multirow[b]{2}{*}{$\mathrm{lb} / \mathrm{Mbtu}$} & \multicolumn{3}{|c|}{ Reduced SOx } \\
\hline & & & & & & & ppmv & $\mathrm{Ib} / \mathrm{h}$ & $\mathrm{lb} / \mathrm{Mbtu}$ \\
\hline $\mathrm{CO}$ & 133 & 538 & 0.14 & 282 & 215 & 0.06 & 284 & 205 & 0.05 \\
\hline $\mathrm{SO} 2$ & 35 & 328 & 0.08 & 5349 & 9349 & 2.40 & 3837 & 6326 & 1.62 \\
\hline $\mathrm{SO} 3$ & 2.4 & 28.0 & 0.0073 & 66.7 & 145.7 & 0.0374 & 47.4 & 97.7 & 0.0251 \\
\hline NOx & 40 & 267 & 0.069 & 388 & 522 & 0.134 & 391 & 496 & 0.127 \\
\hline $\mathrm{NH3}$ & 0.6 & 1.6 & 0.00041 & 0 & 0 & 0 & 0 & 0 & 0 \\
\hline $\mathrm{HCl}$ & 3.7 & 19.4 & 0.00503 & 559.7 & 556.7 & 0.143 & 402.1 & 377.3 & 0.097 \\
\hline PM & & 79 & 0.020 & & 70 & 0.018 & & 66 & 0.017 \\
\hline \multirow[t]{2}{*}{ VOC } & 1.4 & 9.1 & 0.0024 & 1.1 & 1.3 & 0.0003 & 1.2 & 1.3 & 0.0003 \\
\hline & ppbv & $\mathrm{lb} / \mathrm{h}$ & $\mathrm{lb} / \mathrm{Tbtu}$ & ppbv & $\mathrm{lb} / \mathrm{h}$ & lb/Tbtu & ppbv & $\mathrm{lb} / \mathrm{h}$ & lb/Tbtu \\
\hline $\mathrm{Hg}$ & 0.2 & 0.004 & 1.1 & 1.1 & 0.006 & 1.6 & 1.0 & 0.005 & 1.3 \\
\hline
\end{tabular}

\section{Introduction}

Foster Wheeler (FW) was subcontracted to support Praxair's effort of developing $\mathrm{CO}_{2}$ purification technology for existing power plants retrofitted with oxy-fuel fired capability. FW's objective is to perform a technical/economic feasibility study to determine retrofit performance, cost, and interface conditions with the CPU and ASU. To accomplish this objective FW developed a computer simulation process model of the air-fired and oxyfuel-fired pulverized coal (PC) boiler system.

FW is to provide Praxair with plant heat and material balances, estimates of concentrations of trace impurities in the flue gas, a list of oxygen-fired plant modifications and constraints, and an economic assessment of the boiler retrofit. Two fuels were simulated: 1) low sulfur PRB and 2) high sulfur bituminous. This topical report covers the results of both the low sulfur PRB and high sulfur bituminous fuel simulations as well as the economic assessment of the boiler retrofit for both fuels.

\section{Approach}

A system level model and 3-D CFD model of a reference subcritical PC power plant firing either low-sulfur PRB or high-sulfur bituminous coal was created. The Aspen-Plus platform was used to simulate the power plant and the FW-FIRE CFD code was used to determine furnace performance. Simulations were performed at full load (Boiler Maximum Continuous Rating). The reference plant is an existing $460 \mathrm{MWe}$ (gross) power plant.

\section{Design Basis and Assumptions}

Site ambient conditions are listed in Table 2. 
Table 2 - Site Conditions

\begin{tabular}{|r|c|c|}
\hline Elevation & $\mathrm{ft}$ & 7000 \\
Ambient Pressure & psia & 11.3 \\
Ambient Dry Bulb & $\mathrm{F}$ & 87 \\
Ambient Wet Bulb & $\mathrm{F}$ & 61 \\
Ambient Humidity & $\%$ & 26 \\
Condenser Pressure & in Hg & 2.75 \\
Cooling Water Temp. & $\mathrm{F}$ & 76 \\
\hline
\end{tabular}

Coal analysis is presented in Table 3.

Table 3 - Coal Analysis: Low Sulfur and High Sulfur Coals

\begin{tabular}{|r|c||c|c||c|c||}
\hline \multicolumn{1}{|c||}{} & \multicolumn{2}{c||}{ PRB } & \multicolumn{2}{c||}{ Bituminous } \\
\hline C & \multicolumn{1}{l|}{$\% \mathrm{w}$} & 51.47 & 70.60 & 63.75 & 71.73 \\
$\mathrm{H}$ & wet & 3.43 & 4.71 & 4.50 & 5.06 \\
$\mathrm{O}$ & $\% \mathrm{w}$ & 12.73 & 17.46 & 6.88 & 7.74 \\
$\mathrm{~N}$ & $\% \mathrm{w}$ & 0.66 & 0.91 & 1.25 & 1.41 \\
$\mathrm{~S}$ & $\% \mathrm{w}$ & 0.20 & 0.27 & 2.51 & 2.82 \\
Ash & $\% \mathrm{w}$ & 4.40 & 6.04 & 9.70 & 10.91 \\
Moisture & $\% \mathrm{w}$ & 27.10 & 0.00 & 11.12 & 0.00 \\
$\mathrm{He}$ & $\% \mathrm{w}$ & 0.01 & 0.01 & 0.29 & 0.33 \\
\hline sum & $\% \mathrm{w}$ & 100.00 & 100.00 & 100.00 & 100.00 \\
& & & & & \\
HHV & Btu/lb & 8870 & 12167 & 11666 & 13126 \\
$\mathrm{Hg}$ & $\mathrm{ppmdw}$ & 0.8 & & 0.09 & \\
\hline
\end{tabular}

The reference plant selected for this study uses a subcritical steam cycle. Steam cycle conditions are listed in Table 4.

Table 4 - Steam Conditions

\begin{tabular}{|r|c|c|}
\hline Main Steam & & \\
Pressure & $\mathrm{psia}$ & 2415 \\
Temperature & $\mathrm{F}$ & 1000 \\
Flow Rate & $\mathrm{klb} / \mathrm{h}$ & 2990 \\
Reheat Steam & & \\
Pressure & $\mathrm{psia}$ & 600 \\
Temperature & $\mathrm{F}$ & 1000 \\
Flow Rate & $\mathrm{klb} / \mathrm{h}$ & 2630 \\
\hline
\end{tabular}


The reference power plant selected employs a natural circulation boiler, selective catalytic reduction (SCR) for reducing NOx, a wet flue gas desulfurization (FGD) for capturing SOx, and a baghouse to remove particulates. The furnace has a total of 24 opposed wall-fired low NOx Vortex series split-flame burners ( 3 vertical x 4 horizontal x 2 walls) and 10 over-fire air ports. The furnace heat transfer surfaces consist of waterwalls, constructed from MONO-WALLTM finned-tube construction for a gas tight furnace enclosure, radiant superheater partial division walls, and convective finishing superheater and reheater tube banks. After leaving the furnace, flue gas energy is recovered in a parallel-pass convective heat recovery area (HRA) and a regenerative rotary air heater. Final main steam temperature is controlled by spray water attemperation, while reheat steam temperature is controlled by a HRA gas flow proportioning damper, which regulates the flue gas flow to two parallel superheater and reheater passes. Primary air and secondary air are heated in the air heater after which the former is sent to vertical spindle MBF pulverizers to convey the coal and the latter is sent to the furnace windbox. Figure 1 shows a sketch of typical boiler layout.

Figure 1 - Boiler Layout

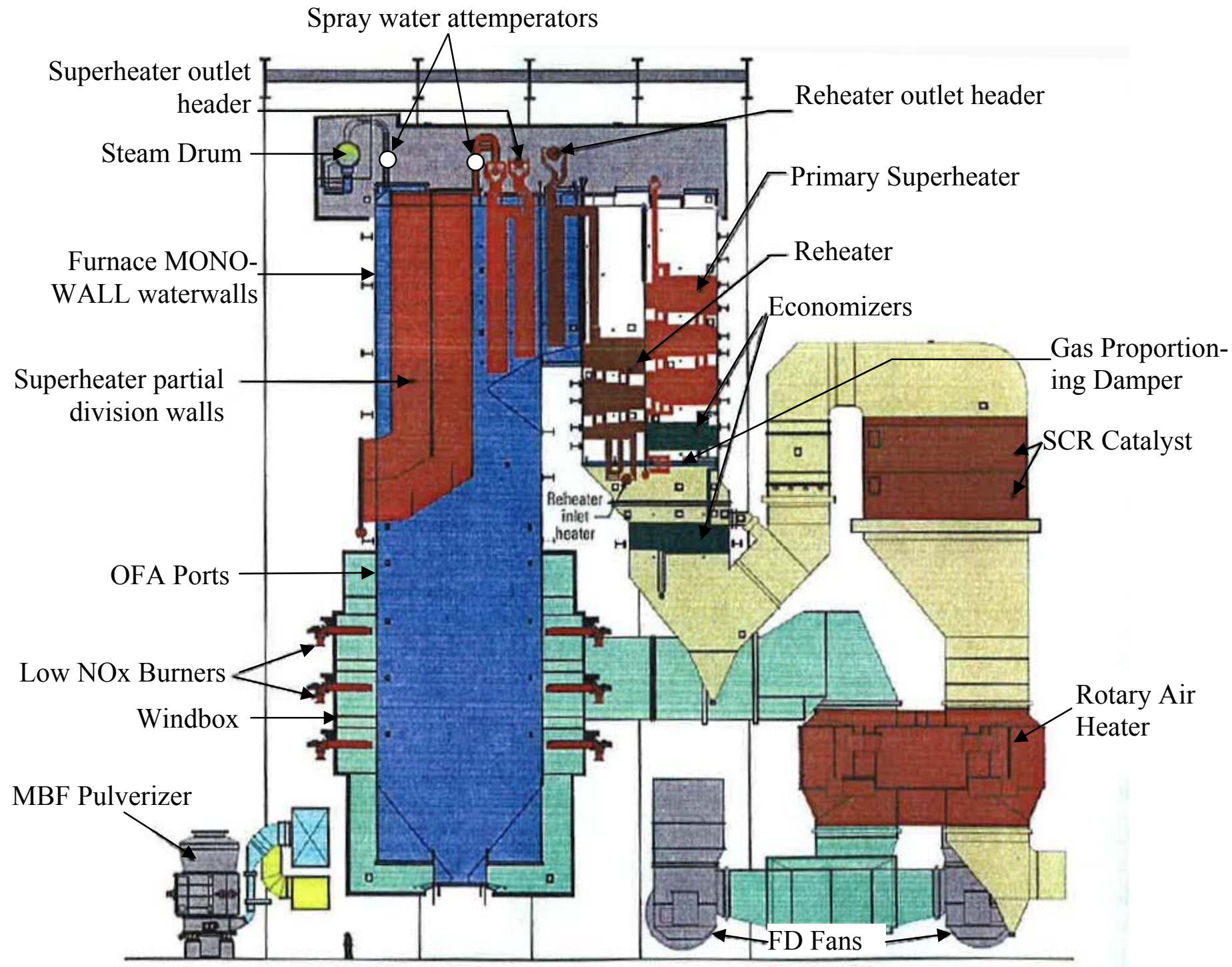


Key assumptions are listed below:

1. For air-fired operation, both FGD and SCR are operating. NOx reduction in SCR is $72 \%$ and SOx capture in FGD is $71 \%$ for PRB coal and $98 \%$ for bituminous coal.

2. For oxy-fired operation, ammonia injection to the SCR unit is shut down; however, any reactions that could be catalyzed by the SCR are assumed to take place such as oxidations of $\mathrm{SO}_{2}$ to $\mathrm{SO}_{3}, \mathrm{CO}$ to $\mathrm{CO}_{2}$, and $\mathrm{Hg}(0)$ to $\mathrm{Hg}(+/++)$, where the extent of oxidation is determined by the catalyst and conditions. Since no data is available for oxy-firing, the same extent/conversion as for air-firing was assumed for the oxy-firing.

3. For oxy-fired operation, the FGD is used to treat a portion of recirculated flue gas, which is then quenched and used as the primary gas stream and part of the secondary gas stream (bituminous only).

4. Air ingress is $2 \%$ (by vol.) of the flue gas exiting the boiler.

5. The purity of oxygen from the ASU is $97 \%$ by volume with $\mathrm{Ar}=2.9 \%$ and $\mathrm{N}_{2}=0.1 \%$.

6. Boiler outlet oxygen concentration (vol.) is $2.4 \%$ for air-firing and $\mathrm{O}_{2}$-firing of PRB fuel and $3.0 \%$ for air-firing and $\mathrm{O}_{2}$ - firing of bituminous fuel

7. Overfire air is $25 \%$ for air-firing, $25 \%$ for $\mathrm{PRB} \mathrm{O}_{2}$-firing and $0 \%$ for bit. $\mathrm{O}_{2}$-firing

8. A boiler design of $1 \%$ margin is applied.

9. Main steam flow was maintained the same for air-firing and $\mathrm{O}_{2}$-firing.

10. To simplify the analysis, the same air-fired furnace design was used for both PRB and bituminous fuels. Although the slagging potential for the PRB and bituminous coals may affect the base air-fired geometry, it will have negligible influence on the retrofit modifications and cost. Note that all specific combustion characteristics of the two fuels (ultimate analysis, heating value, kinetics, etc.) were included.

\section{Air-Fired}

The air-fired power plant model is shown in Figure 2. Heat released from combustion is absorbed in the furnace by waterwalls, division walls, and roof and absorbed by the superheater, reheater, and economizer convective tube bundles in the heat recovery area (HRA). After exiting the economizer, flue gas passes through the selective catalytic reactor (SCR) for NOx control and then through a regenerative air heater to heat up both primary air (PA) and secondary air (SA). Downstream of the air heater, a baghouse (BHG) removes particulates and a flue gas desulfurizer (FGD) captures SOx using a sprayed limestone solution/slurry and reduces the gas temperature by sprayed water. An air ingress of $2 \% \mathrm{v}$ is assumed and lumped into BHG in the model.

Main operational variables are controlled as follows: main steam temperature by two water attemperators, reheat steam temperature by a HRA parallel pass gas damper, pulverizer PA outlet temperature by tempering air, and steam generation by coal firing rate. The same mole fraction of $\mathrm{O}_{2}$ in the furnace flue gas is maintained for both air-firing and oxy-firing.

Emission predictions in the model include $\mathrm{NOx}, \mathrm{SOx}, \mathrm{CO}, \mathrm{PM}, \mathrm{NH}_{3}, \mathrm{VOC}, \mathrm{HCl}$, and $\mathrm{Hg}$. A wet FGD with limestone feed is applied to remove most of SOx to form gypsum $\left(\mathrm{CaSO}_{4} * 2 \mathrm{H}_{2} \mathrm{O}\right)$. For NOx control, the power plant is equipped with low NOx burners, air staging (over-fire air), and SCR. In the model, part of $\mathrm{Hg}$ is oxidized and removed by the combination of $\mathrm{SCR} / \mathrm{BHG} / \mathrm{FGD}$. Fuel-Cl released as $\mathrm{HCl}$ in the furnace is effectively removed with $\mathrm{SOx}$ in the FGD to form $\mathrm{MgCl}_{2}$, which is drained together with gypsum. 
Figure 2 - Aspen-Plus Air-Fired Model

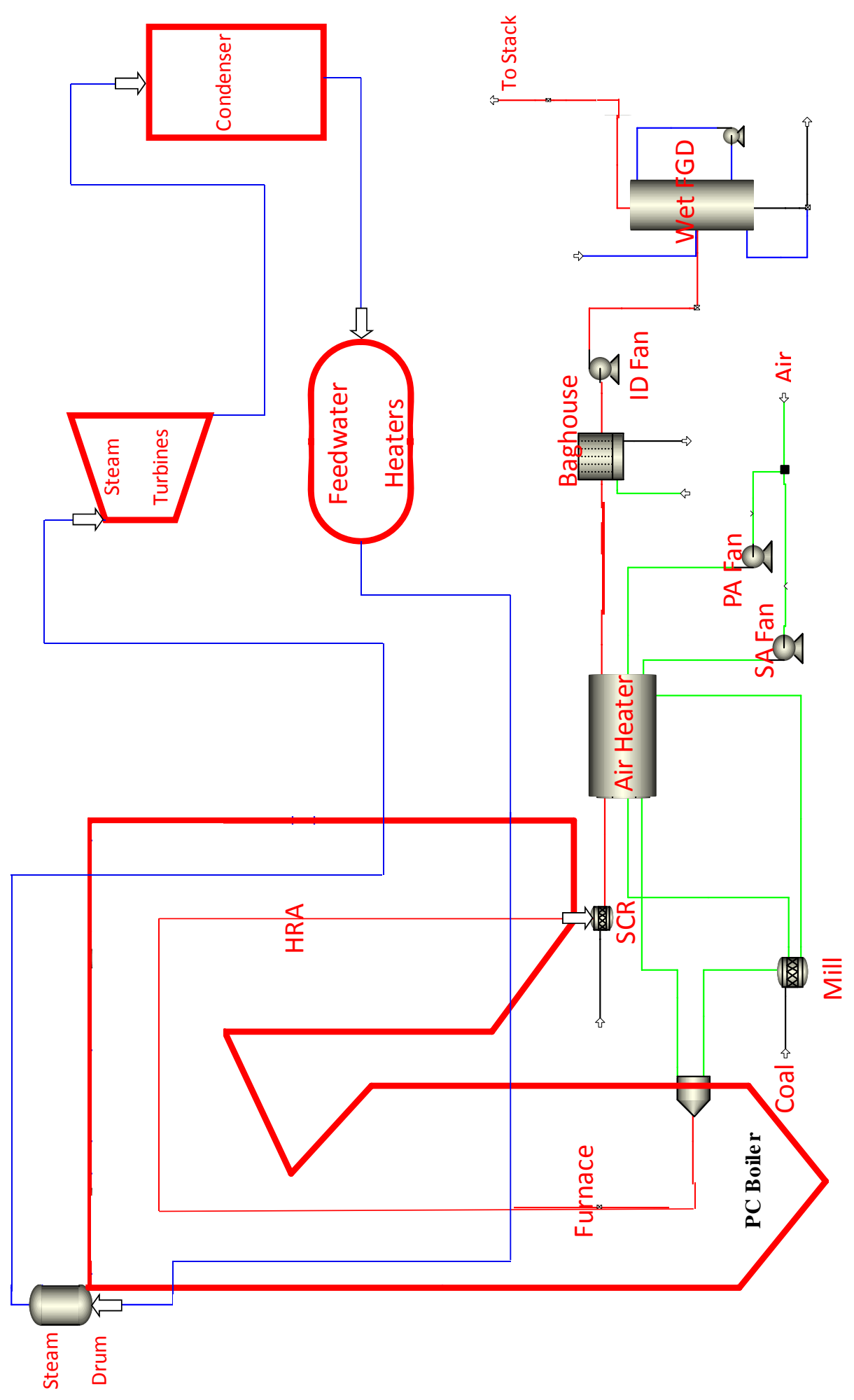




\section{$\mathrm{O}_{2}$-Fired}

The $\mathrm{O}_{2}$-fired power plant model is shown in Figure 3. Modifications to adapt the plant to accommodate oxyfuel firing include the addition of hot/wet and cold/dry flue gas recirculation ducts, oxygen distribution piping, two additional steam extractions for air separation unit (ASU)/ $\mathrm{CO}_{2}$ processing unit (CPU), added flue gas cooler for CPU, increased size of HRA lower economizer, a low pressure economizer downstream of the air-heater, and a quench tower, as well as increased cooling duty and equipment size. In addition for the reduced SOx bituminousfired case a primary gas heater is added.

Secondary gas recycle and gas extracted to the CPU are taken before the FGD and primary gas recycle is taken after the FGD and quench tower since the coal mill requires low moisture nearly SOx-free gas for proper performance and avoidance of acid corrosion. For the reduced SOx bituminous-fired case, secondary gas recycle is split $64 \%$ before the FGD and $36 \%$ after the FGD to limit the boiler corrosive SOx concentration

An additional low pressure economizer is required to cool the gas temperature down in oxyfiring because the air heater functions as a recuperator. The air heater duty is reduced since recycled flue gas flow is less than the air-firing air flow and the secondary gas inlet temperature is significantly higher than the air inlet temperature.

Due to air heater leakage, the $\mathrm{O}_{2}$ from the ASU is not mixed with the recycled gas before the air heater to avoid $\mathrm{O}_{2}$ leakage to the flue gas. Oxygen from the ASU is assumed to be supplied at $97 \% \mathrm{v}$ purity and $120^{\circ} \mathrm{F}$. Oxygen is assumed to be mixed with the secondary gas stream just upstream of the windbox. For proper combustion, some portion of the oxygen may be required to be mixed with the primary gas either at the burners or prior to the burners depending on the burner design and piping constraints.

Steam at about 300 psia and 100 psia is extracted and de-superheated by makeup water from steam cycle, and sent to the ASU and CPU for regeneration and other uses. The return condensate from the ASU and CPU is ducted to deaerator or condenser depending upon its pressure. A working fluid circulation loop (hot water at $950 \mathrm{psia}$ and $525^{\circ} \mathrm{F}$ ) is used to preheat the CPU vent gas (external to the FW model) by fluegas downstream of the SCR. The return water is set to $250^{\circ} \mathrm{F}$ to avoid the acid gas dew point.

Ammonia to the SCR was shut-off, but the SCR catalyst layers remained in place. The FGD is operated at part load to treat only the recycled primary gas stream. Limestone fed to the FGD was reduced to the amount required to remove SOx from the recycled primary gas stream. For the PRB fuel, SOx removal in total is $47 \%$ (as compared to $71 \%$ in the air-fired case). For the bituminous fuel, SOx removal in total is $43 \%$ for the treatment of only the primary gas and $62 \%$ for the reduced SOx case for the treatment of primary gas $+36 \%$ secondary gas (as compared to $98 \%$ in the air-fired case).

Emissions generated in the boiler were predicted by 3-D CFD simulations: NOx and CO by FWFIRE and $\mathrm{SO}_{3}$ by Fluent. For PRB-firing over-fire gas was set at $25 \%$ of the total combustion gas (the same as for air-firing). For bituminous-firing over-fire gas was shut off to increase NOx so as to shift NOx control duty to the CPU (as specified by Praxair). 
Figure 3 - Aspen-Plus $\mathrm{O}_{2}$-Fired Model

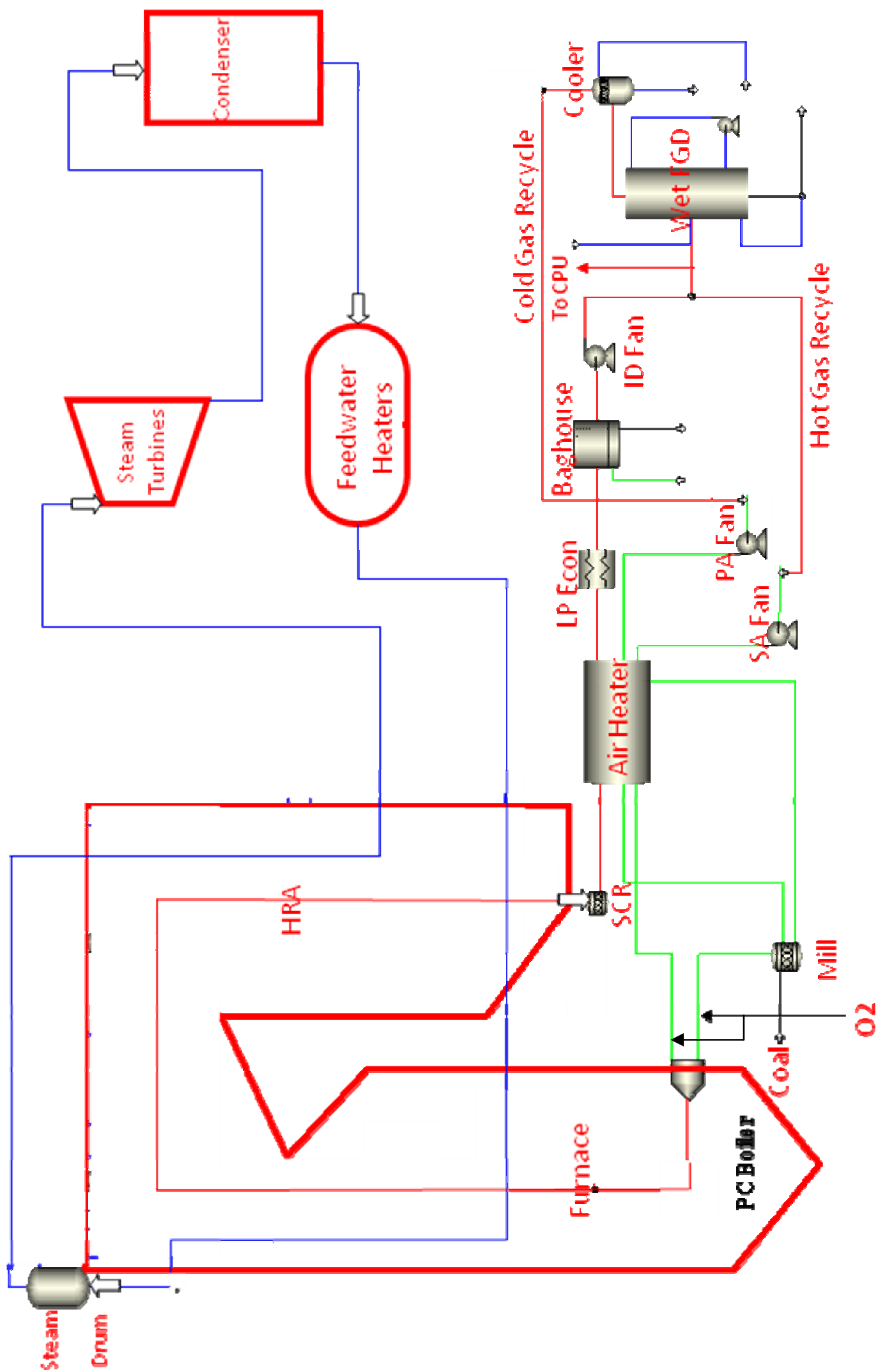

Topical Report by Foster Wheeler for Praxair, Inc. under DE-NT0005341, March 2011

| Page 14 of 52 


\section{Results and Discussion}

\section{Air-Fired Low Sulfur Fuel}

The plant fires $450 \mathrm{klb} / \mathrm{hr}$ of $27 \%$ moisture PRB coal with $15 \%$ excess air to produce $2.99 \mathrm{Mlb} / \mathrm{hr}$ 2415 psia $1000^{\circ} \mathrm{F}$ main steam, $2.63 \mathrm{Mlb} / \mathrm{hr} 603$ psia $1000^{\circ} \mathrm{F}$ reheat steam at the turbine and discharges to the condenser at 2.75" $\mathrm{Hg}$. Plant net efficiency is $35.8 \%$, net power is $418 \mathrm{MWe}$, and boiler efficiency is $86.7 \%$. Power plant feed flow rates are presented in Table 5 and steam cycle auxiliary power is presented in Table 6. Flue gas composition and emissions are presented in Table 7.

The Foster Wheeler CFD computer program, FW-FIRE, was used to determine the furnace performance. The FW-FIRE model simulates the furnace, in height from the bottom of the hopper to the roof, in depth from the front wall to the rear wall, and in width from the left side wall to the right side wall. The furnace model is shown in Figure 4. Figure 5 presents a plot of gas temperature in a vertical plane through the second burner column. The heat flux at the furnace water wall is shown in Figure 6. The maximum heat flux is approximately 70,000 $\mathrm{Btu} / \mathrm{hr}-\mathrm{ft}^{2}$ and the total heat absorbed is $1812 \mathrm{Mbtu} / \mathrm{hr}$. 
Table 5 - Feed Flow Rates: Low Sulfur Fuel

\begin{tabular}{|c|c|c|c|}
\hline Flow Rates & & Air-fired & O2-fired \\
\hline Fuel & $\mathrm{klb} / \mathrm{h}$ & 449 & 452 \\
Air & $\mathrm{klb} / \mathrm{h}$ & 3585 & 0 \\
Oxygen & $\mathrm{klb} / \mathrm{h}$ & 0 & 725 \\
Recirculated Flue Gas & $\mathrm{klb} / \mathrm{h}$ & 0 & 2550 \\
Air Ingress & $\mathrm{klb} / \mathrm{h}$ & 81 & 61 \\
Air Heater Leakage & $\mathrm{klb} / \mathrm{h}$ & 191 & 190 \\
NH3 & $\mathrm{klb} / \mathrm{h}$ & 0.29 & 0 \\
FGD Makeup Water & $\mathrm{klb} / \mathrm{h}$ & 186 & 44 \\
Limestone & $\mathrm{klb} / \mathrm{h}$ & 2.14 & 1.35 \\
Condenser Cooling Water & $\mathrm{k}-\mathrm{gpm}$ & 147 & 156 \\
Total Cooling Water Flow & $\mathrm{k}-\mathrm{gpm}$ & 147 & 232 \\
\hline
\end{tabular}

Table 6 - Steam Cycle Power and Efficiency: Low Sulfur Fuel

\begin{tabular}{|c|c|c|c|}
\hline & & Air-fired & O2-fired \\
\hline Heat in & Mbtu/h & 3980 & 4012 \\
\hline Boiler efficiency & $\%$ & 86.7 & 89.4 \\
\hline Gross Power & MWe & 461 & 467 \\
\hline Aux. Power & MWe & 43 & 38 \\
\hline ASU/CPU Power & MWe & & 125.9 \\
\hline ASU/CPU Cooling Water Power & MWe & & 2.5 \\
\hline Net Power & MWe & 418 & 301 \\
\hline Net efficiency & $\%$ & 35.8 & 25.6 \\
\hline \multicolumn{4}{|c|}{ Auxiliary Power } \\
\hline Cond. Pump & MWe & 0.8 & 0.8 \\
\hline FW Pump & MWe & 12.7 & 12.7 \\
\hline FGD & MWe & 2.9 & 0.8 \\
\hline PA fan & MWe & 2.6 & 1.9 \\
\hline SA fan & MWe & 2.2 & 1.6 \\
\hline ID fan & MWe & 8.3 & 6.4 \\
\hline Pulverizers & MWe & 1.8 & 1.8 \\
\hline Condenser Cooling & MWe & 4.7 & 5.0 \\
\hline others & MWe & 6.9 & 7.0 \\
\hline total & MWe & 42.8 & 37.9 \\
\hline
\end{tabular}


Table 7 - Flue Gas Composition and Emissions: Air-Fired Low Sulfur Fuel

\begin{tabular}{|r|c|c|c|c|c|}
\hline & & \multicolumn{2}{|c|}{ Air-fired } & \multicolumn{2}{c|}{ O2-fired } \\
\hline & & Furnace & Stack & Furnace & To CPU \\
\hline Flow & $\mathrm{klb} / \mathrm{h}$ & 3822 & 4276 & 3517 & 1108 \\
$\mathrm{FEGT}$ & $\mathrm{F}$ & 2202 & 131 & 2164 & 325 \\
$\mathrm{H} 2 \mathrm{O}$ & $\% \mathrm{v}$ & 12.38 & 17.65 & 28.78 & 27.28 \\
$\mathrm{O} 2$ & $\% \mathrm{v}$ & 2.37 & 3.35 & 2.33 & 2.75 \\
$\mathrm{~N} 2$ & $\% \mathrm{v}$ & 69.64 & 65.39 & 4.08 & 5.69 \\
$\mathrm{Ar}$ & $\% \mathrm{v}$ & 0.83 & 0.78 & 2.14 & 2.14 \\
$\mathrm{CO} 2$ & $\% \mathrm{v}$ & 14.73 & 12.80 & 62.57 & 62.05 \\
\hline
\end{tabular}

\begin{tabular}{|r|c|c|c|c|c|c|}
\hline & \multicolumn{3}{|c|}{ Air-Fired at Stack } & \multicolumn{3}{c|}{ O2-Fired to CPU } \\
\hline & $\mathrm{ppmv}$ & $\mathrm{lb} / \mathrm{h}$ & $\mathrm{lb} / \mathrm{Mbtu}$ & $\mathrm{ppmv}$ & $\mathrm{lb} / \mathrm{h}$ & $\mathrm{lb} / \mathrm{Mbtu}$ \\
\hline $\mathrm{CO}$ & 128 & 536 & 0.13 & 280 & 244 & 0.06 \\
$\mathrm{SO} 2$ & 52 & 501 & 0.13 & 465 & 928 & 0.23 \\
$\mathrm{SO} 3$ & 1.3 & 15.8 & 0.0040 & 5.8 & 14.4 & 0.0036 \\
$\mathrm{NOx}$ & 36 & 247 & 0.062 & 156 & 223 & 0.056 \\
$\mathrm{NH3}$ & 0.7 & 1.5 & 0.00037 & 0 & 0 & 0 \\
$\mathrm{HCl}$ & 0.1 & 0.8 & 0.00020 & 18 & 20.9 & 0.0052 \\
$\mathrm{PM}$ & & 49 & 0.012 & & 49 & 0.012 \\
$\mathrm{VOC}$ & 1.8 & 11.9 & 0.0030 & 1.3 & 1.8 & 0.0004 \\
& & & & & & \\
\hline & $\mathrm{ppbv}$ & $\mathrm{Ib} / \mathrm{h}$ & $\mathrm{Ib} / \mathrm{Tbtu}$ & $\mathrm{ppbv}$ & $\mathrm{lb} / \mathrm{h}$ & $\mathrm{lb} / \mathrm{Tbtu}$ \\
$\mathrm{Hg}$ & 1.7 & 0.051 & 12.8 & 10.1 & 0.063 & 15.7 \\
\hline
\end{tabular}


Figure 4 - Furnace Model

(with right side wall removed)

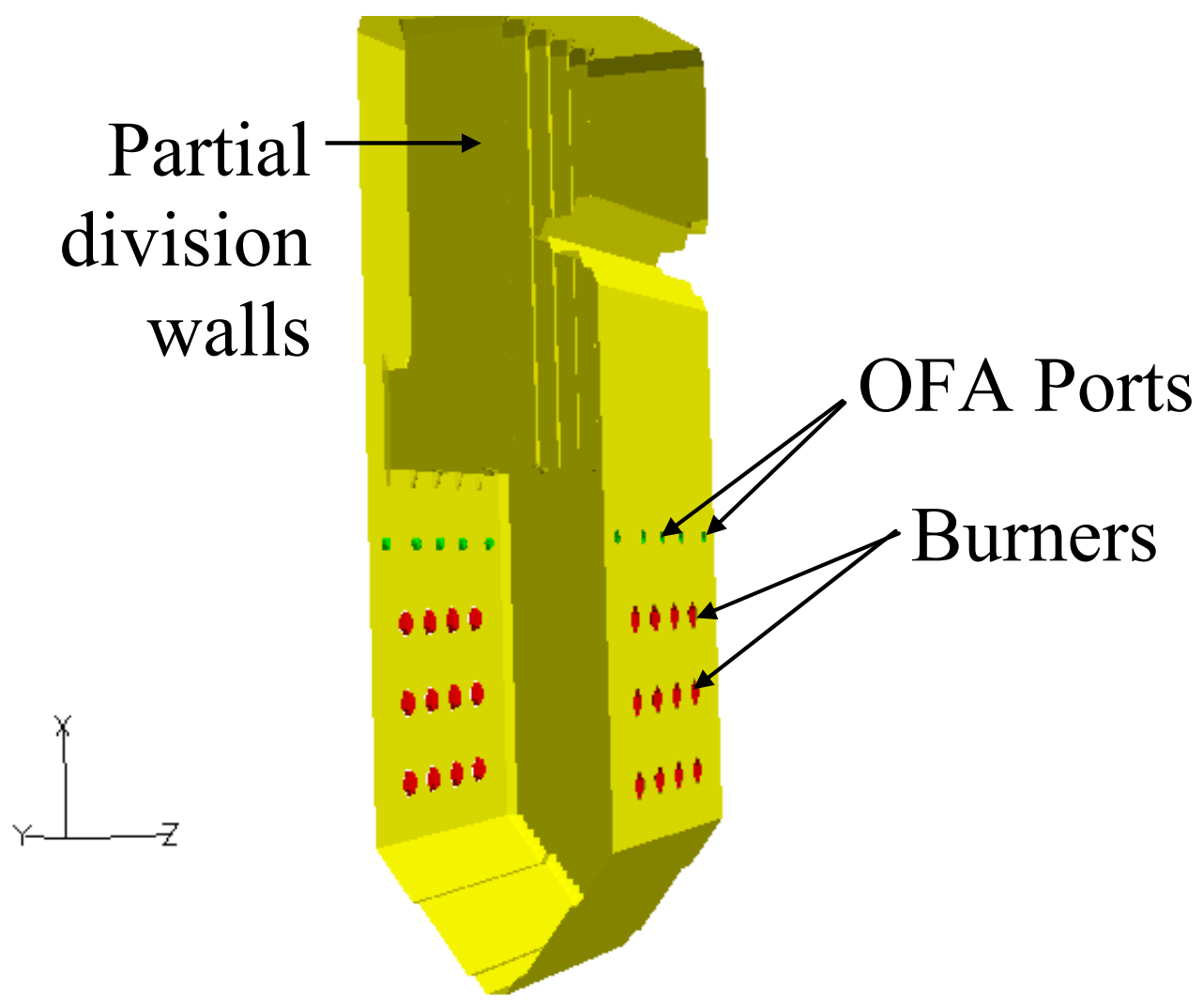


Figure 5 - Gas Temperature: Air-Fired Low Sulfur Fuel

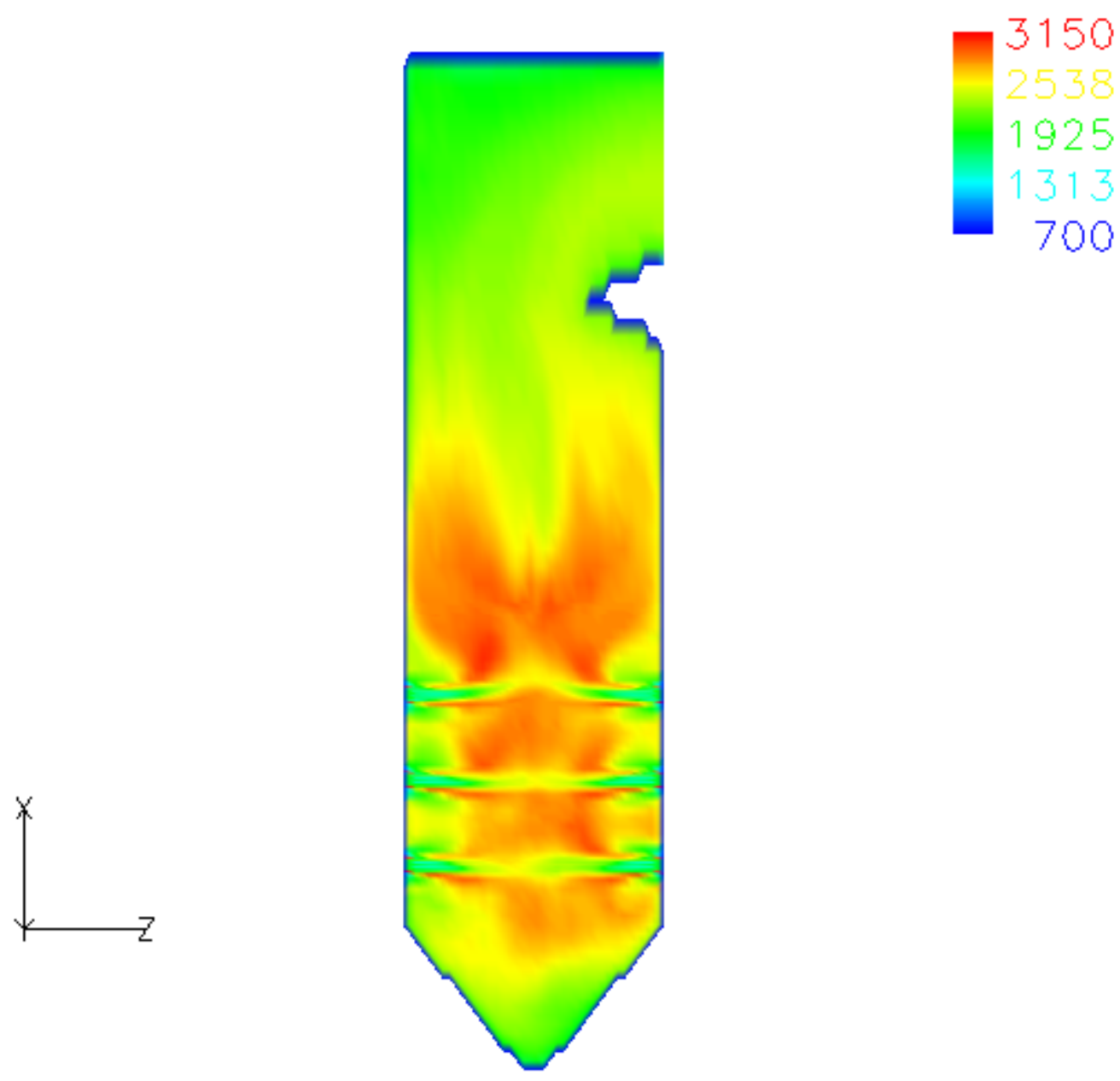


Figure 6 - Wall Heat Flux: Air-Fired Low Sulfur Fuel

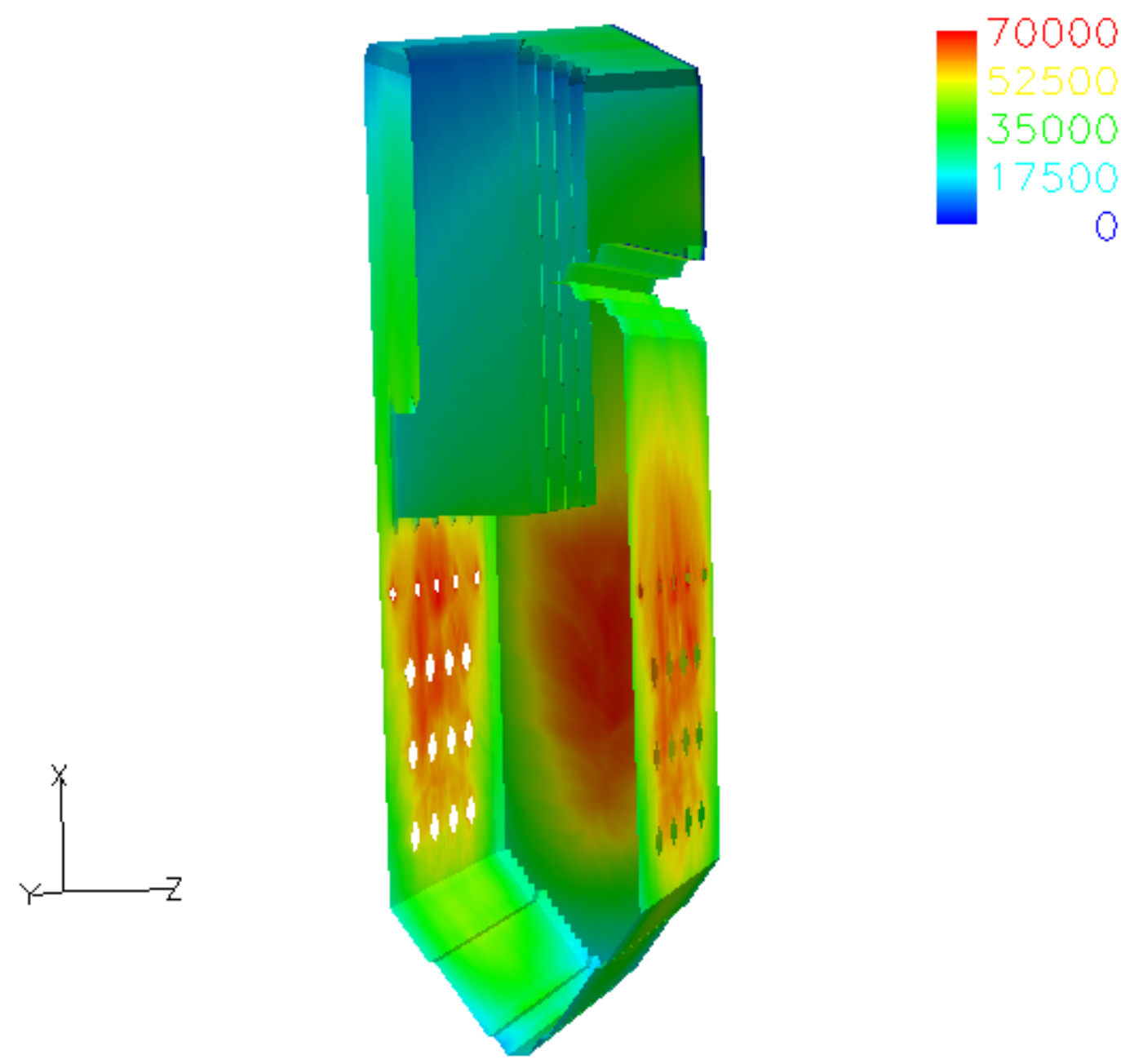




\section{$\mathrm{O}_{2}$-Fired Low Sulfur Fuel}

Iterations were performed between the Aspen-Plus system model and FW-FIRE CFD furnace model to determine the required amount of flue gas recirculation. For a given flue gas recirculation quantity, the firing rate and attemperation were adjusted to make steam flow and temperature. The minimum quantity of flue gas recirculation was selected to match the air-fired heat transfer profile through the boiler. The flue gas recirculation flow to the boiler is $68 \%$ of the flue gas $\left(44 \%\right.$ as secondary gas at $325^{\circ} \mathrm{F}$ after ID fan and $24 \%$ as primary gas at $102^{\circ} \mathrm{F}$ after wet FGD and quenching tower) and is recuperated to $670^{\circ} \mathrm{F}$. Required oxidant flow is $725 \mathrm{klb} / \mathrm{hr}$ and the average $\mathrm{O}_{2}$ in feed gas is $27.4 \% \mathrm{v}$. The fluegas exit $\mathrm{O}_{2}$ concentration is the same as the airfired case at $2.35 \% \mathrm{v}$. Furnace exit gas temperature (FEGT) is $2164^{\circ} \mathrm{F}$, which is about $38^{\circ} \mathrm{F}$ less than for the air-fired case.

The plant fires $452 \mathrm{klb} / \mathrm{hr}$ of PRB coal to produce $2.99 \mathrm{Mlb} / \mathrm{hr} 2415 \mathrm{psia} 1000^{\circ} \mathrm{F}$ main steam, $2.63 \mathrm{Mlb} / \mathrm{hr} 603 \mathrm{psia} 1000^{\circ} \mathrm{F}$ reheat steam at the turbine and discharges to the condenser at $2.75^{\prime \prime}$ $\mathrm{Hg}$. Boiler island gross power is $467 \mathrm{MWe}$, auxiliary power for the boiler is $38 \mathrm{MWe}$, and boiler efficiency is $89.4 \%$. Heat extracted for the ASU and CPU is $47 \mathrm{Mbtu} / \mathrm{hr}$. The boiler island net efficiency is $36.5 \%$ (air-fired boiler net efficiency $=35.8 \%$ ) without counting the power consumption of the ASU and CPU, but including heat extraction to the ASU and CPU (without heat extraction to the ASU and CPU net power would increase by $4.4 \mathrm{MWe}$ ). The lower flue gas flow rate of $\mathrm{O}_{2}$-firing than air-firing increases boiler efficiency due to less heat discharge and reduces auxiliary power due to less fan power. Net efficiency including ASU/CPU duty (125.9 MWe from Praxair) and quench tower and ASU/CPU cooling water duty $(2.5 \mathrm{MWe})$ is $25.6 \%$. $\mathrm{CO}_{2}$ capture efficiency of the CPU is $99 \%$. Power plant feed flow rates are presented in Table 5 and steam cycle auxiliary power is presented in Table 6 . Flue gas composition and emissions are presented in Table 7 . The $\mathrm{CO}_{2}$ purity of the gas to the $\mathrm{CPU}$ is $62.0 \% \mathrm{v}(85.3 \% \mathrm{dv})$.

The lower economizer duty is increased by $28 \%$ compared to air-firing by increasing surface area by $45 \%$. All other HRA banks are the same size and have nearly the same performance as air-firing. Flue gas exiting the HRA is cooled by $10^{\circ} \mathrm{F}$ to heat up the vent gas from the CPU through a circulated working fluid (970 psia hot water). A low pressure economizer (LPECO) is added downstream of air heater to cool the fluegas to $310^{\circ} \mathrm{F}(136 \mathrm{Mbtu} / \mathrm{hr})$ by extracted condensate at $223^{\circ} \mathrm{F}$. The LPECO fully replaces one feedwater heater just before the deaerator. The addition of the LPECO and added economizer surface is required due the reduced duty of the air-air heat exchanger in the $\mathrm{O}_{2}$-fired operation.

The water attemperation flow for control of the main steam temperature is $155 \mathrm{klb} / \mathrm{hr}(5.2 \%)$, which is nearly the same as for the air-fired case $(6.3 \%)$. Due to increased end steam flow of $2097 \mathrm{klb} / \mathrm{hr}$ (Air=2011 klb/hr), the condenser cooling duty in the steam cycle rises to 2009 $\mathrm{Mbtu} / \mathrm{hr}$ (Air=1885 Mbtu/hr) resulting in a cooling water flow increase of $9 \mathrm{k}$-gpm $(4,700 \mathrm{klb} / \mathrm{hr})$ compared to the air-fired case. Additional cooling water is required by the quench tower $(6,300$ $\mathrm{klb} / \mathrm{hr})$ and the ASU/CPU (31,769 klb/hr from Praxair) resulting in additional cooling power load of $2.5 \mathrm{MWe}$. 
Figure 7 - Gas Temperature: $\mathbf{O}_{2}$-Fired Low Sulfur Fuel

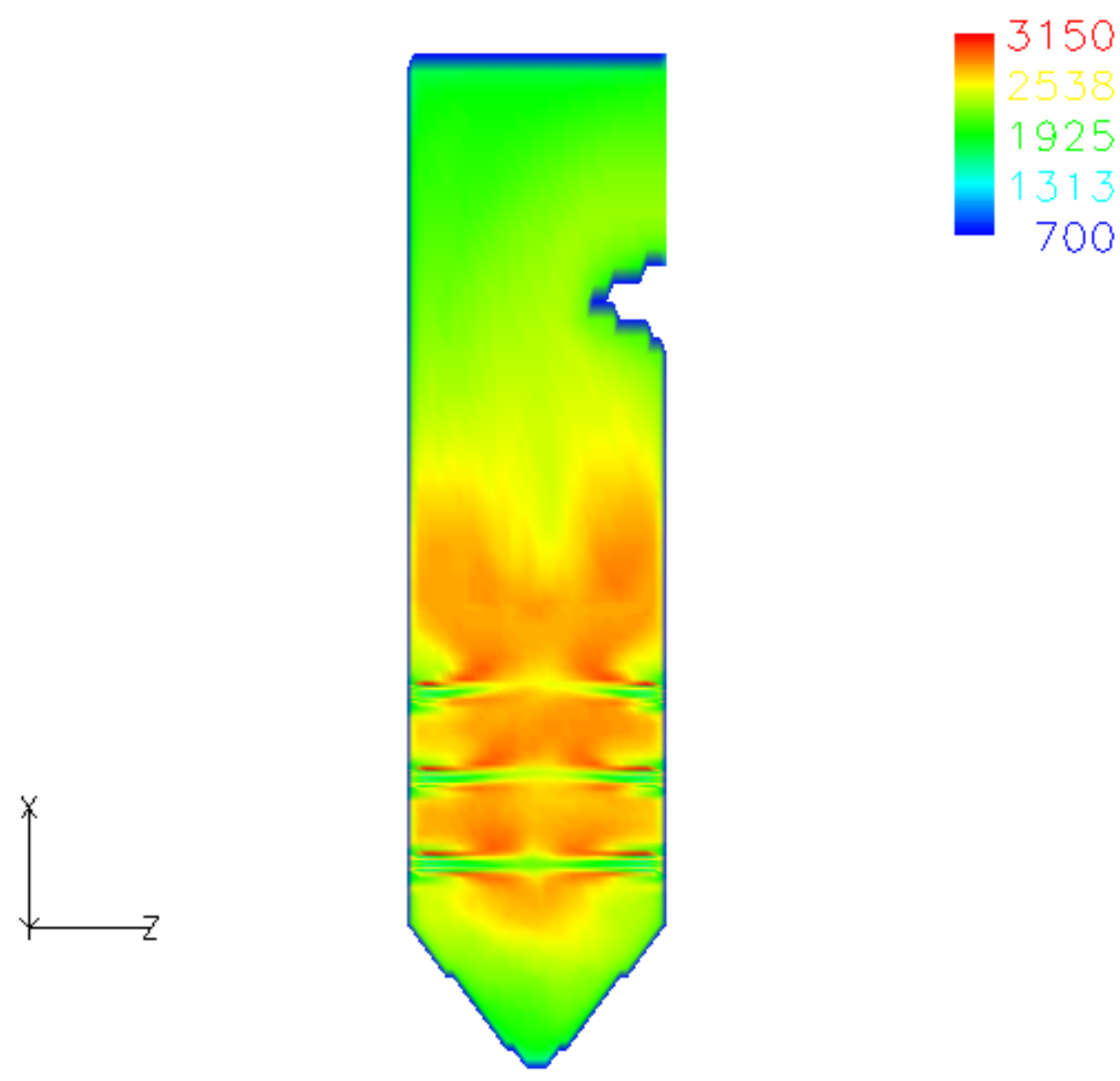


Figure 8 - Wall Heat Flux: $\mathrm{O}_{2}$-Fired Low Sulfur Fuel

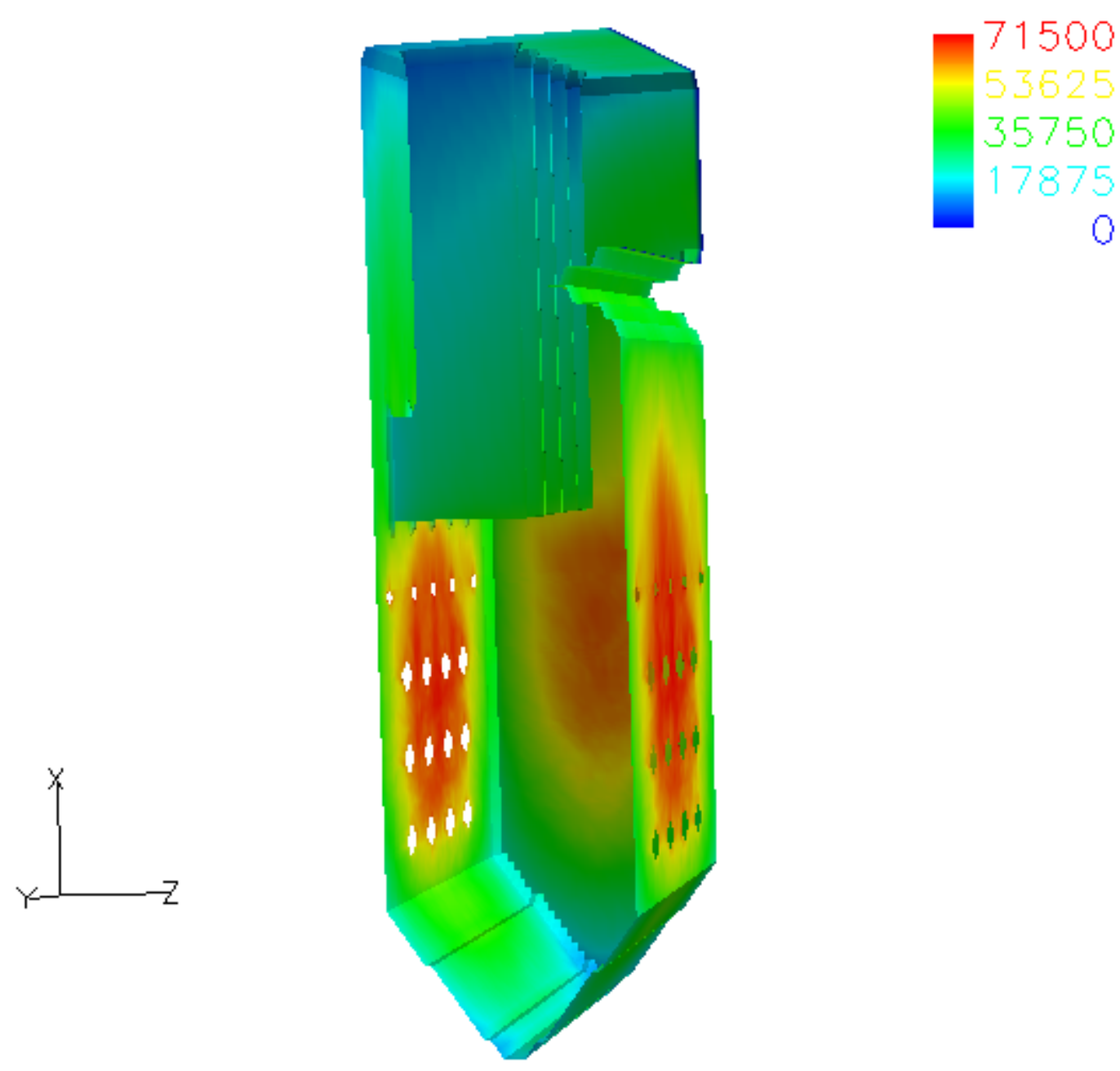


FW-FIRE was used to determine the furnace performance. Figure 7 presents a plot of gas temperature in a vertical plane through the second burner column. The heat flux at the furnace water wall is shown in Figure 8. The maximum heat flux is approximately $71,500 \mathrm{Btu} / \mathrm{hr}-\mathrm{ft}^{2}$ and the total heat absorbed is $1809 \mathrm{Mbtu} / \mathrm{hr}$. The flame shapes and heat flux patterns are nearly identical to those under air-firing indicating the capability of the furnace to operate effectively under $\mathrm{O}_{2}$-firing. Table 8 presents the maximum tube wall temperatures and shows that the maximum increase in wall temperature is less than $10^{\circ} \mathrm{F}$ for oxy-fuel firing.

Table 8 - Maximum Tube Wall Temperatures: O$_{2}$-Fired Low Sulfur Fuel

\begin{tabular}{|r|r|r|r|}
\hline & & Air-Fired & O2-Fired \\
\hline Waterwall & F & 791 & 793 \\
Div Wall & F & 861 & 860 \\
Final SH & F & 1045 & 1049 \\
Final RH & F & 1067 & 1075 \\
Primary SH & F & 787 & 784 \\
Upper Econ & F & 580 & 585 \\
Primary RH & F & 870 & 880 \\
Lower Econ & F & 543 & 552 \\
\hline
\end{tabular}

Since the wet FGD is used to treat only the recycled primary gas (35\% of the recycled gas), the $\mathrm{SO}_{2}$ at furnace exit is about 500 ppmv (assuming 98\% FGD efficiency) compared to air-firing at 210 ppmv. The $\mathrm{SO}_{2}$ leaving the model is $465 \mathrm{ppmv}(0.23 \mathrm{lb} / \mathrm{Mbtu})$ to the CPU compared to airfiring at $52 \mathrm{ppmv}(0.13 \mathrm{lb} / \mathrm{Mbtu})$ to the stack. For the recycled primary flue gas $98 \% \mathrm{SO}_{2}$ is removed by the wet-FGD and water quenching producing a $\mathrm{SO}_{2}$ concentration of $12 \mathrm{ppmv}$.

Fluent was used to determine the $\mathrm{SO}_{3} / \mathrm{SO}_{2}$ conversion. Small amounts of $\mathrm{SO}_{3}$ are formed in the boiler by oxidation of $\mathrm{SO}_{2}$. For air-firing, the ratio of $\mathrm{SO}_{3} / \mathrm{SO}_{2}$ at the furnace outlet was $0.57 \%$. For oxy-firing, the ratio of $\mathrm{SO}_{3} / \mathrm{SO}_{2}$ at the furnace outlet was $0.61 \%$. The outlet $\mathrm{SO}_{3}$ was found to be independent of the amount of $\mathrm{SO}_{3}$ in the recycle flue gas since $\mathrm{SO}_{3}$ is destroyed in the high temperature regions of the furnace and only formed in the upper sections of the furnace as temperature reduces. Furthermore, the ratio of $\mathrm{SO}_{3} / \mathrm{SO}_{2}$ was determined to be independent of the amount of $\mathrm{SO}_{2}$ in the recycle flue gas. Based on these Fluent simulations, it is concluded that the ratio of $\mathrm{SO}_{3} / \mathrm{SO}_{2}$ in the flue gas will be only about $7 \%$ higher for oxy-firing as air-firing. This can be explained by the fact that the formation of $\mathrm{SO}_{3}$ occurs in the upper section of the furnace where the oxy-fired furnace $\mathrm{O}_{2}$ concentration and temperature are very similar to that of the airfired furnace. The $7 \%$ increase for oxy-firing is presumably due to longer residence time of oxyfired flue gas in the furnace (volumetric flow of oxy-fired flue gas is $25 \%$ less than air-fired flue gas). Based on published test results, the $\mathrm{SO}_{3} / \mathrm{SO}_{2}$ generally peaks at about $1 \%$ near the furnace outlet and then decreases to as low as $0.2 \%$ due to adsorption and reaction (i.e. to form $\mathrm{H}_{2} \mathrm{SO}_{4}$ ) with fly ash. For conservatism, the $\mathrm{SO}_{3}$ predicted by Fluent at the furnace outlet is applied. Additional $\mathrm{SO}_{3}$ is created by the $\mathrm{SCR}$ catalyst where approximately $0.5 \%$ of $\mathrm{SO}_{2}$ is oxidized to $\mathrm{SO}_{3}$. Thus, the boiler outlet $\mathrm{SO}_{3}$ concentration is $6.2 \mathrm{ppm}$ for oxy-firing versus $2.5 \mathrm{ppm}$ for airfiring. Model outlet $\mathrm{SO}_{3}$ concentration is $5.8 \mathrm{ppm}(3.6 \mathrm{lb} / \mathrm{Bbtu})$ for oxy-firing versus $1.3 \mathrm{ppm}$ $(4.0 \mathrm{lb} / \mathrm{Bbtu})$ for air-firing. For the recycled primary flue gas $90 \% \mathrm{SO}_{3}$ is removed by the wetFGD and water quenching producing a $\mathrm{SO}_{3}$ concentration of $0.7 \mathrm{ppmv}$. 
FW-FIRE was used to determine boiler outlet NOx. For oxy-firing with no ammonia injection into the SCR (full amount of NOx was recycled in the flue gas) the NOx was predicted to be 156 $\mathrm{ppm}$ at the boiler outlet ( $0.056 \mathrm{lb} / \mathrm{Mbtu}$ to CPU) compared to the air-fired boiler outlet NOx of $147 \mathrm{ppm}(0.25 \mathrm{lb} / \mathrm{Mbtu})$ and SCR outlet NOx of $36 \mathrm{ppm}(0.062 \mathrm{lb} / \mathrm{Mbtu}$ to stack).

FW-FIRE was used to determine boiler outlet $\mathrm{CO}$. For oxy-firing the outlet $\mathrm{CO}$ mole fraction was predicted to be about 2.2 times that of air-firing. The outlet $\mathrm{CO}$ was determined to be independent of the amount of $\mathrm{CO}$ in the recycle flue gas since CO (and likewise VOC) is destroyed in the high temperature high oxygen regions of the near burner region. Thus, the increase in $\mathrm{CO}$ can be explained by the greater equilibrium $\mathrm{CO}$ concentration from oxy-firing which at the equilibrium temperature is approximately 2.3 times that of air-firing. The $\mathrm{CO}$ at the model outlet is predicted to be $280 \mathrm{ppm}(0.061 \mathrm{lb} / \mathrm{Mbtu}$ to the CPU) compared to the air-fired emission of $128 \mathrm{ppm}(0.13 \mathrm{lb} / \mathrm{Mbtu}$ to the stack).

Mercury exits the furnace at $18 \mathrm{ppbv}$ and is reduced to $10 \mathrm{ppbv}(15.7 \mathrm{lb} / \mathrm{Tbtu})$ by the SCR catalyst (removed mercury remains in the catalyst and ash) before exiting to the CPU compared to the air-fired boiler outlet $\mathrm{Hg}$ of $1.4 \mathrm{ppbv}(10.5 \mathrm{lb} / \mathrm{Tbtu})$ to the stack. For the recycled primary flue gas all $\mathrm{Hg}$ is essentially removed by the wet-FGD due to reduced loading and by water quenching by cooling the fluegas to a low temperature.

$\mathrm{HCl}$ exits the furnace and the model (to the $\mathrm{CPU}$ ) at $20 \mathrm{ppmv}(5.2 \mathrm{lb} / \mathrm{Bbtu})$ compared to the airfired boiler outlet $\mathrm{HCl}$ of $0.14 \mathrm{ppmv}(0.2 \mathrm{lb} / \mathrm{Bbtu})$. For the recycled primary flue gas nearly all $\mathrm{HCl}$ is removed by the wet-FGD and water quenching.

\section{Air-Fired High Sulfur Fuel}

The plant fires $331 \mathrm{klb} / \mathrm{hr}$ of $11 \%$ moisture bituminous coal with $18 \%$ excess air to produce 2.99 $\mathrm{Mlb} / \mathrm{hr} 2415 \mathrm{psia} 1000^{\circ} \mathrm{F}$ main steam, $2.63 \mathrm{Mlb} / \mathrm{hr} 603 \mathrm{psia} 1000^{\circ} \mathrm{F}$ reheat steam at the turbine and discharges to the condenser at $2.75^{\prime \prime} \mathrm{Hg}$. Plant net efficiency is $36.7 \%$, net power is 416 MWe, and boiler efficiency is $89.3 \%$. Power plant feed flow rates are presented in Table 9 and steam cycle auxiliary power is presented in Table 10. Flue gas composition and emissions are presented in Table 11.

The Foster Wheeler CFD computer program, FW-FIRE, was used to determine the furnace performance. The furnace model is shown in Figure 4 (same geometry as for PRB-fired). Figure 9 presents a plot of gas temperature in a vertical plane through the second burner column. The heat flux at the furnace water wall is shown in Figure 10. The maximum heat flux is approximately $76,000 \mathrm{Btu} / \mathrm{hr}^{-\mathrm{ft}^{2}}$ and the total heat absorbed is $1887 \mathrm{Mbtu} / \mathrm{hr}$. 
Table 9 - Feed Flow Rates: High Sulfur Fuel

\begin{tabular}{|c|c|c|c|c|}
\hline Flow Rates & & Air-fired & \multicolumn{2}{|c|}{ O2-fired } \\
\hline & & & & Low SOx \\
\hline Fuel & $\mathrm{klb} / \mathrm{h}$ & 331 & 334 & 334 \\
Air & $\mathrm{klb} / \mathrm{h}$ & 3567 & 0 & 0 \\
Oxygen & $\mathrm{klb} / \mathrm{h}$ & 0 & 712 & 712 \\
Recirculated Flue Gas & $\mathrm{klb} / \mathrm{h}$ & 0 & 2754 & 2829 \\
Air Ingress & $\mathrm{klb} / \mathrm{h}$ & 77 & 60 & 60 \\
Air Heater Leakage & $\mathrm{klb} / \mathrm{h}$ & 150 & 149 & 149 \\
NH3 & $\mathrm{klb} / \mathrm{h}$ & 0.32 & 0 & 0 \\
FGD Water Makeup & $\mathrm{klb} / \mathrm{h}$ & 235 & 61 & 101 \\
Limestone & $\mathrm{klb} / \mathrm{h}$ & 27.2 & 12.0 & 17.1 \\
Condenser Cooling Water & $\mathrm{k}-\mathrm{gpm}$ & 147 & 152 & 154 \\
Total Cooling Water Flow & $\mathrm{k}-\mathrm{gpm}$ & 147 & 226 & 228 \\
\hline
\end{tabular}

Table 10 - Steam Cycle Power and Efficiency: High Sulfur Fuel

\begin{tabular}{r|c|c|c|c|}
\hline & & Air-fired & \multicolumn{2}{|c|}{ O2-fired } \\
\hline Heat in & Mbtu/h & 3861 & 3893 & 3894 \\
Boiler efficiency & $\%$ & 89.3 & 92.1 & 92.4 \\
Gross Power & MWe & 460 & 467 & 465 \\
Aux. Power & MWe & 45 & 38 & 40 \\
ASU/CPU Power & MWe & & 119.7 & 119.7 \\
ASU/CPU Cooling Water Power & MWe & & 2.4 & 2.4 \\
Net Power & MWe & 416 & 306 & 304 \\
Net efficiency & $\%$ & 36.7 & 26.9 & 26.6 \\
\hline \multicolumn{4}{|r|}{ Auxiliary Power } & \\
\hline Cond. Pump & MWe & 0.8 & 0.8 & 0.8 \\
FW Pump & MWe & 12.7 & 12.7 & 12.7 \\
FGD & MWe & 6.1 & 2.1 & 3.3 \\
PA fan & MWe & 2.0 & 1.5 & 1.5 \\
SA fan & MWe & 2.4 & 1.9 & 1.8 \\
ID fan & MWe & 7.8 & 6.3 & 6.3 \\
Pulverizers & MWe & 1.3 & 1.3 & 1.3 \\
others & MWe & 6.9 & 7.0 & 7.0 \\
total & MWe & 44.6 & 38.4 & 39.5 \\
\hline Condenser Cooling & MWe & 4.7 & 4.9 & 5.0 \\
\hline
\end{tabular}


Table 11 - Flue Gas Composition and Emissions: Air-Fired High Sulfur Fuel

\begin{tabular}{|r|c|c|c|c|c|c|c|}
\hline & & \multicolumn{2}{|c|}{ Air-fired } & \multicolumn{4}{c|}{ O2-fired } \\
\hline & & Furnace & Stack & Furnace & To CPU & Furnace & To CPU \\
\hline & & & & & & \multicolumn{3}{|c|}{ Reduced SOx } \\
\hline Flow & $\mathrm{klb} / \mathrm{h}$ & 3715 & 4129 & 3618 & 1002 & 3693 & 971 \\
$\mathrm{FEGT}$ & $\mathrm{F}$ & 2199 & 127 & 2112 & 325 & 2119 & 310 \\
$\mathrm{H} 2 \mathrm{O}$ & $\% \mathrm{v}$ & 8.93 & 15.85 & 23.46 & 22.45 & 19.01 & 18.25 \\
$\mathrm{O} 2$ & $\% \mathrm{v}$ & 2.99 & 3.63 & 2.94 & 3.32 & 2.93 & 3.31 \\
$\mathrm{~N} 2$ & $\% \mathrm{v}$ & 72.97 & 67.55 & 4.99 & 6.54 & 5.36 & 6.88 \\
$\mathrm{Ar}$ & $\% \mathrm{v}$ & 0.87 & 0.81 & 2.41 & 2.40 & 2.56 & 2.54 \\
$\mathrm{CO} 2$ & $\% \mathrm{v}$ & 13.99 & 12.14 & 65.50 & 64.63 & 69.62 & 68.53 \\
\hline
\end{tabular}

\begin{tabular}{|c|c|c|c|c|c|c|c|c|c|}
\hline & \multicolumn{3}{|c|}{ Air-Fired at Stack } & \multicolumn{6}{|c|}{ O2-Fired to CPU } \\
\hline & \multirow[b]{2}{*}{ ppmv } & \multirow[b]{2}{*}{$\mathrm{lb} / \mathrm{h}$} & \multirow[b]{2}{*}{$\mathrm{lb} / \mathrm{Mbtu}$} & \multirow[b]{2}{*}{ ppmv } & \multirow[b]{2}{*}{$\mathrm{lb} / \mathrm{h}$} & \multirow[b]{2}{*}{$\mathrm{lb} / \mathrm{Mbtu}$} & \multicolumn{3}{|c|}{ Reduced SOx } \\
\hline & & & & & & & ppmv & $\mathrm{lb} / \mathrm{h}$ & $\mathrm{lb} / \mathrm{Mbtu}$ \\
\hline $\mathrm{CO}$ & 133 & 538 & 0.14 & 282 & 215 & 0.06 & 284 & 205 & 0.05 \\
\hline $\mathrm{SO} 2$ & 35 & 328 & 0.08 & 5349 & 9349 & 2.40 & 3837 & 6326 & 1.62 \\
\hline $\mathrm{SO} 3$ & 2.4 & 28.0 & 0.0073 & 66.7 & 145.7 & 0.0374 & 47.4 & 97.7 & 0.0251 \\
\hline NOx & 40 & 267 & 0.069 & 388 & 522 & 0.134 & 391 & 496 & 0.127 \\
\hline $\mathrm{NH} 3$ & 0.6 & 1.6 & 0.00041 & 0 & 0 & 0 & 0 & 0 & 0 \\
\hline $\mathrm{HCl}$ & 3.7 & 19.4 & 0.00503 & 559.7 & 556.7 & 0.143 & 402.1 & 377.3 & 0.097 \\
\hline PM & & 79 & 0.020 & & 70 & 0.018 & & 66 & 0.017 \\
\hline \multirow[t]{2}{*}{ VOC } & 1.4 & 9.1 & 0.0024 & 1.1 & 1.3 & 0.0003 & 1.2 & 1.3 & 0.0003 \\
\hline & ppbv & $\mathrm{lb} / \mathrm{h}$ & $\mathrm{lb} / \mathrm{Tbtu}$ & ppbv & $\mathrm{lb} / \mathrm{h}$ & $\mathrm{lb} / \mathrm{Tbtu}$ & ppbv & $\mathrm{Ib} / \mathrm{h}$ & $\mathrm{lb} / \mathrm{Tbtu}$ \\
\hline $\mathrm{Hg}$ & 0.2 & 0.004 & 1.1 & 1.1 & 0.006 & 1.6 & 1.0 & 0.005 & 1.3 \\
\hline
\end{tabular}


Figure 9 - Gas Temperature: Air-Fired High Sulfur Fuel

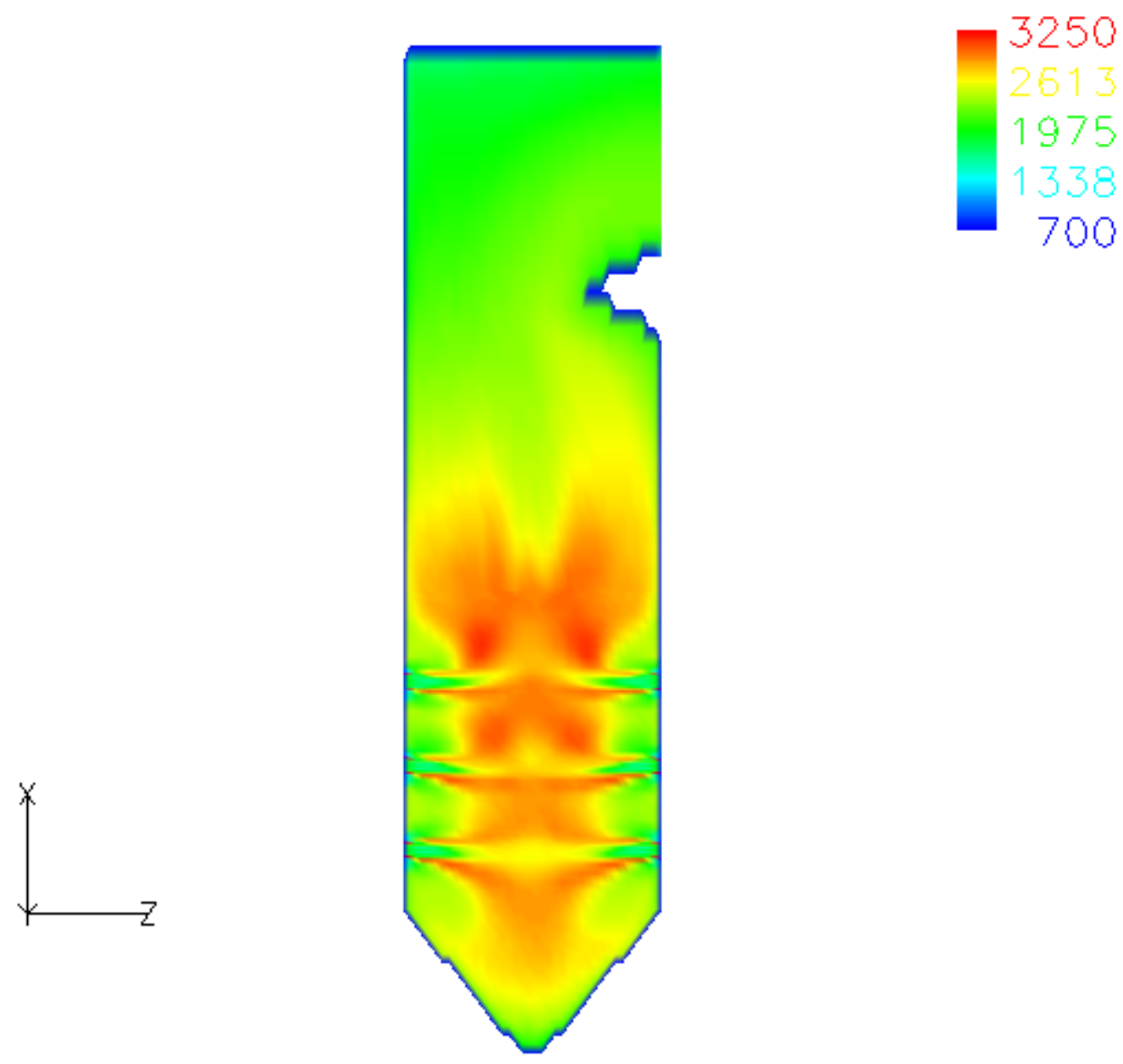


Figure 10 - Wall Heat Flux: Air-Fired High Sulfur Fuel

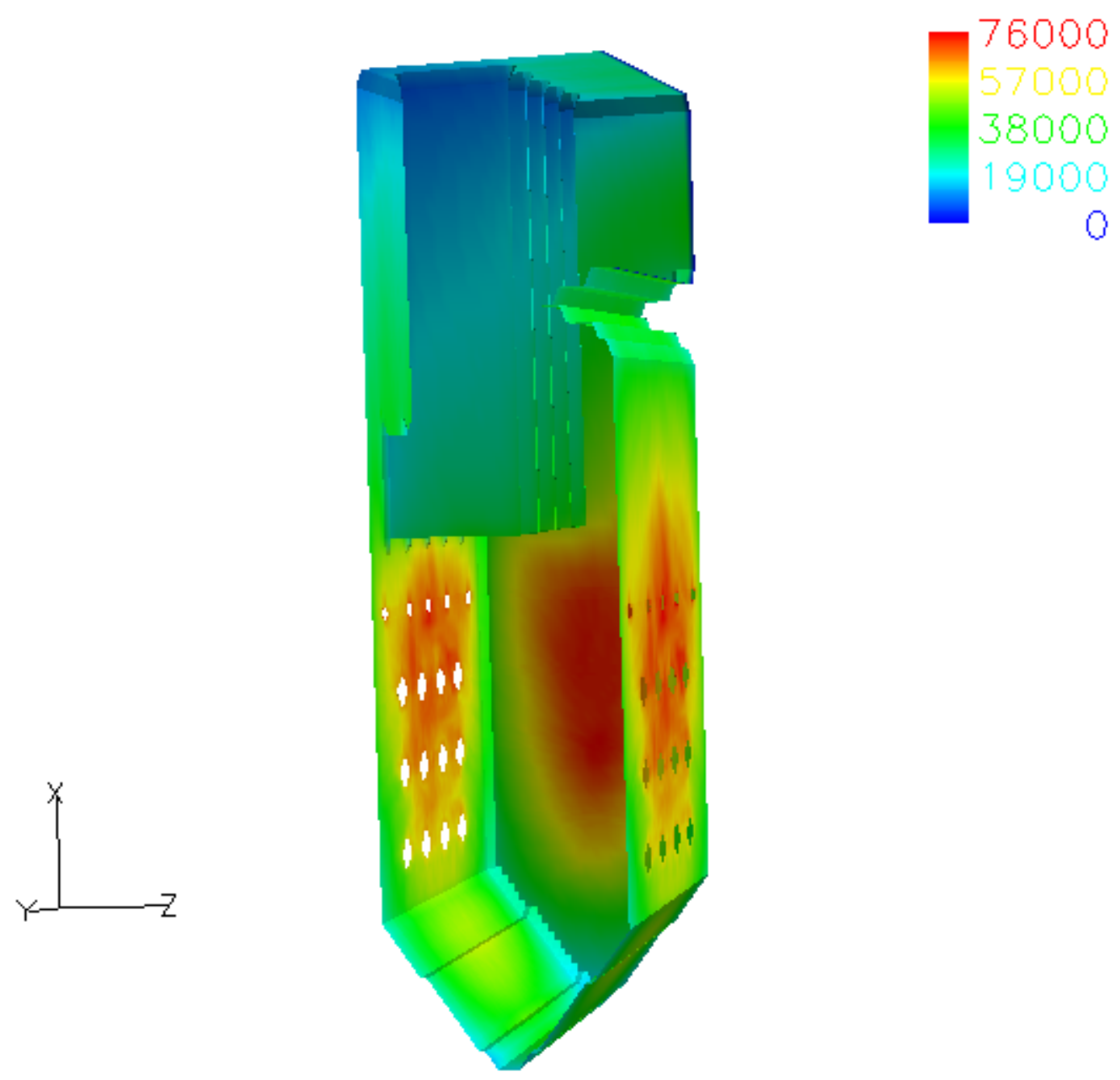




\section{$\mathrm{O}_{2}$-Fired High Sulfur Fuel: High SOx}

Iterations were performed between the Aspen-Plus system model and FW-FIRE CFD furnace model to determine the required amount of flue gas recirculation. The quantity of flue gas recirculation was selected to minimize changes to the boiler by approximately matching heat transfer and maximum metal temperatures. The flue gas recirculation flow to the boiler is $72 \%$ of the flue gas $\left(54 \%\right.$ as secondary gas at $310^{\circ} \mathrm{F}$ after ID fan and $18 \%$ as primary gas at $102^{\circ} \mathrm{F}$ after wet FGD and quenching tower) and is recuperated to $675^{\circ} \mathrm{F}$. Required oxidant flow is $712 \mathrm{klb} / \mathrm{hr}$ and the average $\mathrm{O}_{2}$ in feed gas is $27.2 \% \mathrm{v}$. The fluegas exit $\mathrm{O}_{2}$ concentration is the same as the air-fired case at $3.0 \% \mathrm{v}$. Furnace exit gas temperature (FEGT) is $2112^{\circ} \mathrm{F}$, which is about $87^{\circ} \mathrm{F}$ less than for the air-fired case.

The plant fires $334 \mathrm{klb} / \mathrm{hr}$ of bituminous coal to produce $2.99 \mathrm{Mlb} / \mathrm{hr} 2415$ psia $1000^{\circ} \mathrm{F}$ main steam, $2.63 \mathrm{Mlb} / \mathrm{hr} 603 \mathrm{psia} 1000^{\circ} \mathrm{F}$ reheat steam at the turbine and discharges to the condenser at $2.75^{\prime \prime} \mathrm{Hg}$. Boiler island gross power is $467 \mathrm{MWe}$, auxiliary power for the boiler is $38 \mathrm{MWe}$, and boiler efficiency is $92.1 \%$. Heat extracted for the ASU and CPU is $47 \mathrm{Mbtu} / \mathrm{hr}$. The boiler island net efficiency is $37.4 \%$ (air-fired boiler net efficiency $=36.7 \%$ ) without counting the power consumption of the ASU and CPU, but including heat extraction to the ASU and CPU (without heat extraction to the ASU and CPU net power would increase by $4.4 \mathrm{MWe}$ ). Net efficiency including ASU/CPU duty (119.7 MWe from Praxair) and quench tower and CPU cooling water duty $(2.4 \mathrm{MWe})$ is $26.9 \%$. $\mathrm{CO}_{2}$ capture efficiency of the $\mathrm{CPU}$ is $99 \%$.

Power plant feed flow rates are presented in Table 9 and steam cycle auxiliary power is presented in Table 10. Flue gas composition and emissions are presented in Table 11. The $\mathrm{CO}_{2}$ purity of the gas to the $\mathrm{CPU}$ is $64.6 \% \mathrm{v}(83.3 \% \mathrm{dv})$.

The lower economizer duty is increased by $35 \%$ compared to air-firing by increasing surface area by $45 \%$. All other HRA banks are the same size and have nearly the same performance as air-firing. Flue gas exiting the HRA is cooled by $10^{\circ} \mathrm{F}$ to heat up the vent gas from the CPU through a circulated working fluid (970 psia hot water). A low pressure economizer (LPECO) is added downstream of air heater to cool the fluegas to $310^{\circ} \mathrm{F}(135 \mathrm{Mbtu} / \mathrm{hr})$ by extracted condensate at $223^{\circ} \mathrm{F}$. The LPECO fully replaces one feedwater heater just before the deaerator.

The water attemperation flow for control of the main steam temperature is $72 \mathrm{klb} / \mathrm{hr}(2.6 \%)$, which is less than for the air-fired case (3.9\%). Due to increased end steam flow of $2096 \mathrm{klb} / \mathrm{hr}$ (Air=2010 klb/hr), the condenser cooling duty in the steam cycle rises to $1965 \mathrm{Mbtu} / \mathrm{hr}$ (Air=1884 Mbtu/hr) resulting in a cooling water flow increase of $6 \mathrm{k}$-gpm compared to the airfired case. Additional cooling water is required by the quench tower $(7,200 \mathrm{klb} / \mathrm{hr})$ and the ASU/CPU (29,671 klb/hr from Praxair) resulting in additional cooling power load of 2.4 MWe.

The maximum heat flux is approximately $82,500 \mathrm{Btu} / \mathrm{hr}-\mathrm{ft}^{2}$ and the total heat absorbed is 1872 $\mathrm{Mbtu} / \mathrm{hr}$. 
Since the wet FGD is used to treat only the recycled primary gas (23\% of the recycled gas), the $\mathrm{SO}_{2}$ at furnace exit is about 5690 ppmv (assuming 99\% FGD efficiency) compared to air-firing at $205 \mathrm{ppmv}$. The $\mathrm{SO}_{2}$ leaving the model is $5350 \mathrm{ppmv}(2.4 \mathrm{lb} / \mathrm{Mbtu})$ to the CPU compared to air-firing at $35 \mathrm{ppmv}(0.08 \mathrm{lb} / \mathrm{Mbtu})$ to the stack. For the recycled primary flue gas $99 \% \mathrm{SO}_{2}$ is removed by the wet-FGD and water quenching producing a $\mathrm{SO}_{2}$ concentration of 63 ppmv. This SOx level of $5690 \mathrm{ppm}$ is comparable to an air-fired unit burning $6.9 \%$ (7.7\% dry) sulfur coal.

FW-FIRE was used to determine boiler outlet NOx. For oxy-firing with no ammonia injection into the SCR (full amount of NOx was recycled in the flue gas) the NOx was predicted to be 388 ppm at the boiler outlet ( $0.134 \mathrm{lb} / \mathrm{Mbtu}$ to CPU) compared to the air-fired boiler outlet NOx of $166 \mathrm{ppm}(0.25 \mathrm{lb} / \mathrm{Mbtu})$ and SCR outlet NOx of $40 \mathrm{ppm}$ (0.069 lb/Mbtu to stack).

FW-FIRE was used to determine boiler outlet CO. For oxy-firing the outlet CO mole fraction was predicted to be about 2.1 times that of air-firing. The outlet $\mathrm{CO}$ was determined to be independent of the amount of $\mathrm{CO}$ in the recycle flue gas since $\mathrm{CO}$ (and likewise VOC) is destroyed in the high temperature high oxygen regions of the near burner region. Thus, the increase in $\mathrm{CO}$ can be explained by the greater equilibrium $\mathrm{CO}$ concentration for oxy-firing which at the equilibrium temperature is approximately 2.1 times that of air-firing. The $\mathrm{CO}$ at the model outlet is predicted to be $282 \mathrm{ppm}(0.055 \mathrm{lb} / \mathrm{Mbtu}$ to the CPU) compared to the air-fired emission of $133 \mathrm{ppm}(0.14 \mathrm{lb} /$ Mbtu to the stack).

Mercury exits the furnace at $2.0 \mathrm{ppbv}$ and is reduced to $1.1 \mathrm{ppbv}(1.6 \mathrm{lb} / \mathrm{Tbtu})$ by the SCR catalyst before exiting to the CPU compared to the air-fired boiler outlet $\mathrm{Hg}$ of $0.2 \mathrm{ppbv}$ (1.1 $\mathrm{lb} / \mathrm{Tbtu})$. For the recycled primary flue gas all $\mathrm{Hg}$ is essentially removed by the wet-FGD and water quenching.

$\mathrm{HCl}$ exits the furnace and the model (to the CPU) at $560 \mathrm{ppmv}(143 \mathrm{lb} / \mathrm{Bbtu}$ ) compared to the air-fired boiler outlet $\mathrm{HCl}$ of $3.7 \mathrm{ppmv}(5.0 \mathrm{lb} / \mathrm{Bbtu})$. For the recycled primary flue gas nearly all $\mathrm{HCl}$ is removed by the wet-FGD and water quenching.

\section{$\mathrm{O}_{2}$-Fired High Sulfur Fuel: Reduced SOx}

To reduce the potential for boiler corrosion, a case was run with reduced SOx in the boiler. Waterwall (lower furnace) corrosion is function of waterwall temperature and the deposit and gas composition. Since in $\mathrm{O}_{2}$-firing compared to air-firing, the waterwall temperature is nearly the same and the composition of the ash deposit is not expected to change significantly, the predominant effect on waterwall corrosion is from the gas composition. The most important corrosive gas species is $\mathrm{H}_{2} \mathrm{~S}$, which occurs in reducing conditions, especially due to combustion staging. In general, switching from air-firing to $\mathrm{O}_{2}$-firing increases the level of $\mathrm{H}_{2} \mathrm{~S}$ by $50-100 \%$. However, because in the current design, the OFA is reduced from $25 \%$ to $0 \%$ when switching from air to $\mathrm{O}_{2}$, the maximum $\mathrm{H}_{2} \mathrm{~S}$ actually decreases by nearly $50 \%$. Consequently the corrosion of the waterwalls is not expected to be an issue even when only the primary gas is treated by the FGD.

However, superheater/reheater corrosion is caused by the presence of liquid alkali iron trisulfates that form on tube surfaces beneath the ash deposit and is a function of the alkali content of the deposited ash and the SOx concentration in the upper furnace (oxidizing conditions). As shown 


\section{'Near Zero Emissions Oxy-Combustion Flue Gas Purification - Power Plant Performance}

in the previous section, without any FGD treatment of the secondary gas, the SOx level is 5690 ppm which corresponds to the air-firing of a 7.7\% S (dry) coal (compared to the air-fired SOx of $2100 \mathrm{ppm}$ ). Consequently, it may be necessary to treat a portion of the secondary gas by the FGD depending on the maximum SOx level for which the superheater/reheater materials were designed. After a survey of operating FW units, a reasonable upper limit for SOx was judged to be about $4000 \mathrm{ppm}$ (corresponding to air-firing of a 5.5\% S (dry) coal). This was applied as the rough minimum FGD treatment objective. However, a more rigorous material corrosion investigation is required to determine what level of FGD treatment is actually required for specific boiler materials, fuels, and boiler conditions. Such an investigation is currently being performed by FW under DOE/NETL contract, DE- NT0005262, the results of which could be used, when available, to establish a more accurate minimum FGD treatment.

Iterations were performed between the Aspen-Plus system model and FW-FIRE CFD furnace model to determine the required amount of flue gas recirculation. The quantity of flue gas recirculation was selected to minimize changes to the boiler by approximately matching heat transfer and maximum metal temperatures. The flue gas recirculation flow to the boiler is $72 \%$ of the flue gas $\left(34 \%\right.$ as secondary gas at $310^{\circ} \mathrm{F}$ after ID fan and $38 \%$ as primary + secondary gas at $102^{\circ} \mathrm{F}$ after wet FGD and quenching tower) and is recuperated to $675^{\circ} \mathrm{F}$. Required oxidant flow is $712 \mathrm{klb} / \mathrm{hr}$ and the average $\mathrm{O}_{2}$ in feed gas is $26.4 \% \mathrm{v}$. The fluegas exit $\mathrm{O}_{2}$ concentration is the same as the air-fired case at $3.0 \% \mathrm{v}$. Furnace exit gas temperature (FEGT) is $2119^{\circ} \mathrm{F}$, which is about $80^{\circ} \mathrm{F}$ less than for the air-fired case.

The plant fires $334 \mathrm{klb} / \mathrm{hr}$ of bituminous coal to produce $2.99 \mathrm{Mlb} / \mathrm{hr} 2415 \mathrm{psia} 1000^{\circ} \mathrm{F}$ main steam, $2.63 \mathrm{Mlb} / \mathrm{hr} 603 \mathrm{psia} 1000^{\circ} \mathrm{F}$ reheat steam at the turbine and discharges to the condenser at $2.75^{\prime \prime} \mathrm{Hg}$. Boiler island gross power is $465 \mathrm{MWe}$, auxiliary power for the boiler is $40 \mathrm{MWe}$, and boiler efficiency is $92.4 \%$. Heat extracted for the ASU and CPU is $47 \mathrm{Mbtu} / \mathrm{hr}$. The boiler island net efficiency is $37.3 \%$ (air-fired boiler net efficiency $=36.7 \%$ ) without counting the power consumption of the ASU and CPU, but including heat extraction to the ASU and CPU (without heat extraction to the ASU and CPU net power would increase by $4.4 \mathrm{MWe}$ ). Net efficiency including ASU/CPU duty (119.7 MWe from Praxair) and quench tower and ASU/CPU cooling water duty $(2.4 \mathrm{MWe})$ is $26.6 \% . \mathrm{CO}_{2}$ capture efficiency of the CPU is over $99 \%$.

Power plant feed flow rates are presented in Table 9 and steam cycle auxiliary power is presented in Table 10. Flue gas composition and emissions are presented in Table 11 . The $\mathrm{CO}_{2}$ purity of the gas to the CPU is $68.5 \% \mathrm{v}(83.8 \% \mathrm{dv})$.

The lower economizer duty is increased by 35\% compared to air-firing by increasing surface area by $45 \%$. All other HRA banks are the same size and have nearly the same performance as air-firing. Flue gas exiting the $\mathrm{HRA}$ is cooled by $10^{\circ} \mathrm{F}$ to heat up the vent gas from the CPU through a circulated working fluid (970 psia hot water). A low pressure economizer (LPECO) is added downstream of air heater to cool the fluegas to $322^{\circ} \mathrm{F}(107 \mathrm{Mbtu} / \mathrm{hr})$ by extracted condensate at $223^{\circ} \mathrm{F}$. The LPECO fully replaces one feedwater heater just before the deaerator. A tubular gas-to-gas heater is added downstream of the ID fan to heat the secondary gas, which passed through the FGD, from $102^{\circ} \mathrm{F}$ to $253^{\circ} \mathrm{F}$ by cooling the flue gas to $310^{\circ} \mathrm{F}(26 \mathrm{Mbtu} / \mathrm{hr})$. This heating is required to avoid acid gas dew point corrosion after mixing with the high SOx secondary gas (without FGD treatment). 
The water attemperation flow for control of the main steam temperature is $78 \mathrm{klb} / \mathrm{hr}(2.8 \%)$, which is slightly less than for the air-fired case (3.9\%). Due to increased end steam flow of 2074 $\mathrm{klb} / \mathrm{hr}$ (Air=2010 klb/hr), the condenser cooling duty in the steam cycle rises to $1981 \mathrm{Mbtu} / \mathrm{hr}$ (Air=1884 Mbtu/hr) resulting in a cooling water flow increase of $7 \mathrm{k}$-gpm $(3,700 \mathrm{klb} / \mathrm{hr}$ ) compared to the air-fired case. Additional cooling water is required by the quench tower $(7,200$ $\mathrm{klb} / \mathrm{hr})$ and the ASU/CPU $(29,671 \mathrm{k} / \mathrm{hr}$ from Praxair) resulting in additional cooling power load of $2.4 \mathrm{MWe}$.

FW-FIRE was used to determine the furnace performance. Figure 11 presents a plot of gas temperature in a vertical plane through the second burner column. The heat flux at the furnace water wall is shown in Figure 12. The maximum heat flux is approximately $82,300 \mathrm{Btu} / \mathrm{hr}-\mathrm{ft}^{2}$ and the total heat absorbed is $1863 \mathrm{Mbtu} / \mathrm{hr}$. The flame shapes and heat flux patterns are nearly identical to those under air-firing indicating the capability of the furnace to operate effectively under $\mathrm{O}_{2}$-firing. Table 12 presents the maximum tube wall temperatures and shows that the maximum increase in wall temperature is less than $10^{\circ} \mathrm{F}$ for oxy-fuel firing. 
Figure 11 - Gas Temperature: $\mathbf{O}_{2}$-Fired High Sulfur Fuel, Reduced Sox

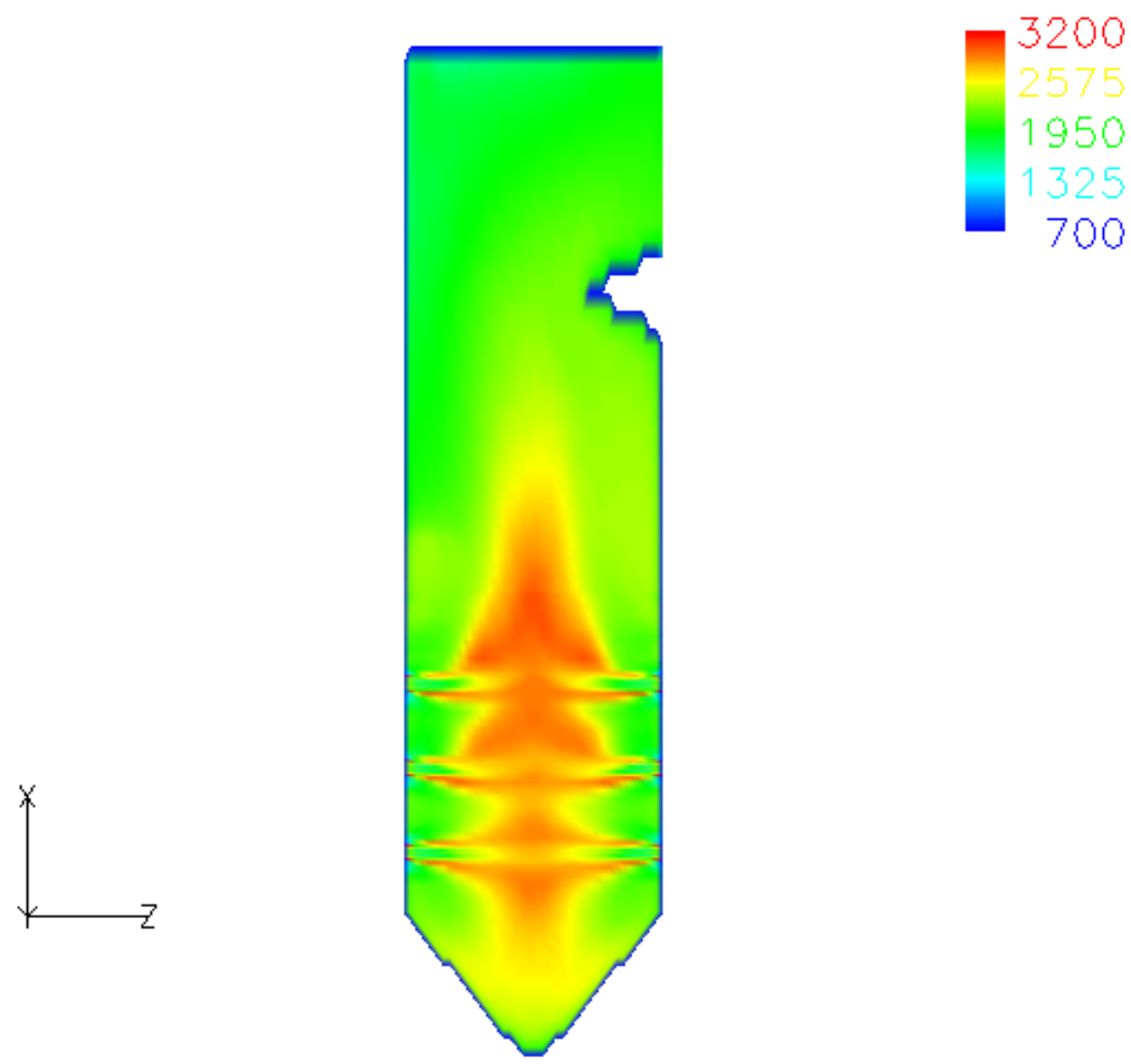


Figure 12 - Wall Heat Flux: $\mathrm{O}_{2}$-Fired High Sulfur Fuel, Reduced SOx
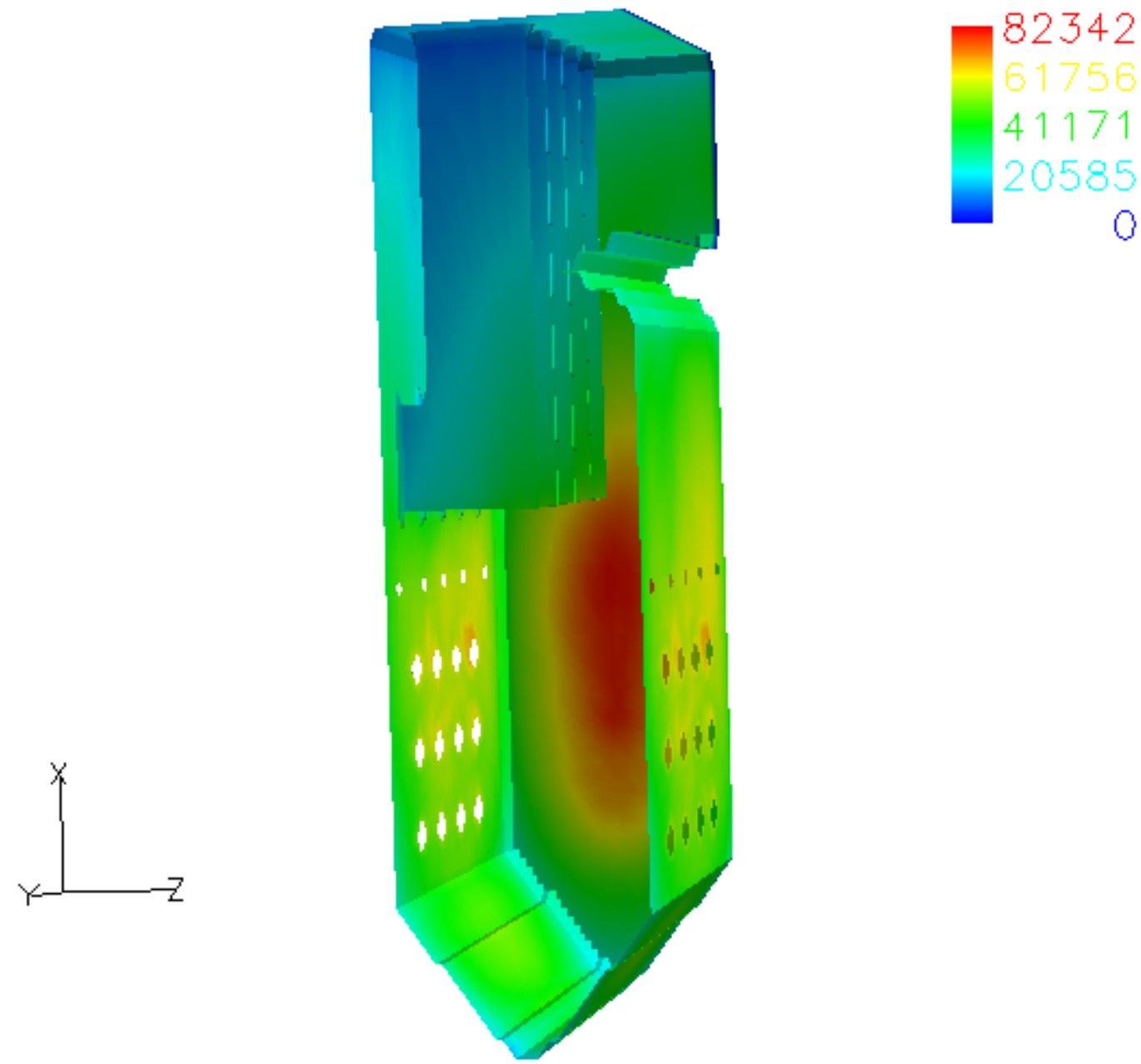
Table 12 - Maximum Tube Wall Temperatures: $\mathbf{O}_{2}$-Fired High Sulfur Fuel

\begin{tabular}{|c|c|r|r|r|}
\hline & & Air-Fired & $\mathrm{O}_{2}$-Fired & $\mathrm{O}_{2}$-Fired \\
\hline Wall Temp. & & & & $\begin{array}{c}\text { Reduced } \\
\text { SOx }\end{array}$ \\
\cline { 1 - 2 } Waterwall & $\mathrm{F}$ & 802 & 811 & 810 \\
Div Wall & $\mathrm{F}$ & 858 & 861 & 862 \\
Final SH & $\mathrm{F}$ & 1042 & 1045 & 1044 \\
Final RH & $\mathrm{F}$ & 1065 & 1068 & 1069 \\
Primary SH & $\mathrm{F}$ & 777 & 771 & 772 \\
Upper Econ & $\mathrm{F}$ & 573 & 578 & 581 \\
Primary RH & $\mathrm{F}$ & 879 & 886 & 886 \\
Lower Econ & $\mathrm{F}$ & 543 & 551 & 552 \\
\hline
\end{tabular}

Since the wet FGD is used to treat the recycled primary gas $+36 \%$ of the secondary gas $(55 \%$ of the recycled gas is treated by FGD), the $\mathrm{SO}_{2}$ at furnace exit is about $4080 \mathrm{ppmv}$ (assuming $99 \%$ FGD efficiency) compared to air-firing at 205 ppmv. The $\mathrm{SO}_{2}$ leaving the model is $3840 \mathrm{ppmv}$ $(1.6 \mathrm{lb} / \mathrm{Mbtu})$ to the CPU compared to air-firing at $35 \mathrm{ppmv}(0.08 \mathrm{lb} / \mathrm{Mbtu})$ to the stack. For the FGD treatment of the recycled primary flue gas and $36 \%$ of the secondary flue gas, $99 \% \mathrm{SO}_{2}$ is removed by the wet-FGD and water quenching producing a $\mathrm{SO}_{2}$ concentration of $43 \mathrm{ppmv}$ in the recycled flue gas.

Fluent was used to determine the $\mathrm{SO}_{3} / \mathrm{SO}_{2}$ conversion. Small amounts of $\mathrm{SO}_{3}$ are formed in the boiler by oxidation of $\mathrm{SO}_{2}$. For air-firing, the ratio of $\mathrm{SO}_{3} / \mathrm{SO}_{2}$ at the furnace outlet was $0.65 \%$. For oxy-firing with no OFA, the ratio of $\mathrm{SO}_{3} / \mathrm{SO}_{2}$ at the furnace outlet was $0.73 \%$. The outlet $\mathrm{SO}_{3}$ was found to be independent of the amount of $\mathrm{SO}_{3}$ in the recycle flue gas since $\mathrm{SO}_{3}$ is destroyed in the high temperature regions of the furnace and only formed in the upper sections of the furnace as temperature reduces. Furthermore, the ratio of $\mathrm{SO}_{3} / \mathrm{SO}_{2}$ was determined to be independent of the amount of $\mathrm{SO}_{2}$ in the recycle flue gas. Based on these Fluent simulations, it is concluded that the ratio of $\mathrm{SO}_{3} / \mathrm{SO}_{2}$ in the flue gas will be only about $12 \%$ higher for oxy-firing as air-firing. This can be explained by the fact that the formation of $\mathrm{SO}_{3}$ occurs in the upper section of the furnace where the oxy-fired furnace $\mathrm{O}_{2}$ concentration and temperature are very similar to that of the air-fired furnace. The $12 \%$ increase for oxy-firing is presumably due to longer residence time of oxy-fired flue gas in the furnace (volumetric flow of oxy-fired flue gas is $22 \%$ less than air-fired flue gas). Based on published test results, the $\mathrm{SO}_{3} / \mathrm{SO}_{2}$ generally peaks at about $1 \%$ near the furnace outlet and then decreases to as low as $0.2 \%$ due to adsorption and reaction (i.e. to form $\mathrm{H}_{2} \mathrm{SO}_{4}$ ) with fly ash. For conservatism, the $\mathrm{SO}_{3}$ predicted by Fluent at the furnace outlet is applied. Additional $\mathrm{SO}_{3}$ is created by the $\mathrm{SCR}$ catalyst where approximately $0.5 \%$ of $\mathrm{SO}_{2}$ is oxidized to $\mathrm{SO}_{3}$. Thus, the boiler outlet $\mathrm{SO}_{3}$ concentration is $50.1 \mathrm{ppm}$ for oxyfiring versus $13.4 \mathrm{ppm}$ for air-firing. Model outlet $\mathrm{SO}_{3}$ concentration is $47.4 \mathrm{ppm}(25.1 \mathrm{lb} / \mathrm{Bbtu})$ for oxy-firing versus $2.4 \mathrm{ppm}(7.3 \mathrm{lb} / \mathrm{Bbtu})$ for air-firing. For the recycled primary flue gas $95 \%$ $\mathrm{SO}_{3}$ is removed by the wet-FGD and water quenching producing a $\mathrm{SO}_{3}$ concentration of 2.7 ppmv. This $\mathrm{SO}_{3}$ concentration can be reduced to $1.6 \mathrm{ppmv}$ by removing the SCR catalyst, which may be required to protect the mill from acid corrosion. Normally $\mathrm{H}_{2} \mathrm{SO}_{4}$ levels and not $\mathrm{SO}_{3}$ 
levels are measured at the stack due to the operating temperatures at the test locations. The $\mathrm{SO}_{3}$ levels noted here are the precursors to the $\mathrm{H}_{2} \mathrm{SO}_{4}$ levels tested at the stack in air-firing.

FW-FIRE was used to determine boiler outlet NOx. For oxy-firing with no ammonia injection into the SCR (full amount of NOx was recycled in the flue gas) the NOx was predicted to be 397 $\mathrm{ppm}$ at the boiler outlet $(0.127 \mathrm{lb} / \mathrm{Mbtu}$ to CPU) compared to the air-fired boiler outlet NOx of $166 \mathrm{ppm}(0.25 \mathrm{lb} / \mathrm{Mbtu})$ and SCR outlet NOx of $40 \mathrm{ppm}(0.069 \mathrm{lb} / \mathrm{Mbtu}$ to stack).

FW-FIRE was used to determine boiler outlet CO. For oxy-firing the outlet $\mathrm{CO}$ mole fraction was predicted to be about 2.1 times that of air-firing. The outlet $\mathrm{CO}$ was determined to be independent of the amount of $\mathrm{CO}$ in the recycle flue gas since $\mathrm{CO}$ (and likewise VOC) is destroyed in the high temperature high oxygen regions near the burners. Thus, the increase in $\mathrm{CO}$ can be explained by the greater equilibrium $\mathrm{CO}$ concentration for oxy-firing, which at the equilibrium temperature is approximately 2.1 times that of air-firing. The $\mathrm{CO}$ at the model outlet is predicted to be $284 \mathrm{ppm}(0.053 \mathrm{lb} / \mathrm{Mbtu}$ to the $\mathrm{CPU})$ compared to the air-fired emission of 133 ppm $(0.14 \mathrm{lb} /$ Mbtu to the stack).

Mercury exits the furnace at $1.7 \mathrm{ppbv}$ and is reduced to $1.0 \mathrm{ppbv}(1.3 \mathrm{lb} / \mathrm{Tbtu})$ by the SCR catalyst before exiting to the CPU compared to the air-fired boiler outlet $\mathrm{Hg}$ of $0.2 \mathrm{ppbv}$ (1.1 $\mathrm{lb} / \mathrm{Tbtu}$ ). For the recycled primary flue gas all $\mathrm{Hg}$ is essentially removed by the wet-FGD and water quenching.

$\mathrm{HCl}$ exits the furnace and the model (to the CPU) at $402 \mathrm{ppmv}(97 \mathrm{lb} / \mathrm{Bbtu}$ ) compared to the airfired boiler outlet $\mathrm{HCl}$ of $3.7 \mathrm{ppmv}(5.0 \mathrm{lb} / \mathrm{Bbtu})$. For the recycled primary flue gas nearly all $\mathrm{HCl}$ is removed by the wet-FGD and water quenching.

\section{Summary of Power Plant Retrofit Modifications}

\section{$\mathrm{O}_{2}$-Fired Low Sulfur Fuel}

1. HRA lower economizer enlargement

Additional surface area $=22,250 \mathrm{ft}^{2}\left(\right.$ total surface area $\left.=72,350 \mathrm{ft}^{2}\right)$.

Total heat transfer $=170 \mathrm{Mbtu} / \mathrm{hr}$

Inlet $/$ Outlet Water temperature $=495^{\circ} \mathrm{F} / 546^{\circ} \mathrm{F}$ (total lower economizer)

Water flow rate $=2845 \mathrm{klb} / \mathrm{hr}$

$\mathrm{LMTD}=285^{\circ} \mathrm{F}$ (total lower economizer)

2. Low pressure economizer

Surface area $=144,200 \mathrm{ft}^{2}$ (Some tubes may require special coating to avoid flue gas acid corrosion)

Heat transfer $=135 \mathrm{Mbtu} / \mathrm{hr}$

Inlet $/$ outlet water temperature $=223^{\circ} \mathrm{F} / 280^{\circ} \mathrm{F}$

Water flow rate $=2376 \mathrm{klb} / \mathrm{hr}$

$\mathrm{LMTD}=125^{\circ} \mathrm{F}$

3. $\mathrm{O}_{2}$ distribution $\left(725 \mathrm{klb} / \mathrm{hr}\right.$ at $\left.120^{\circ} \mathrm{F}\right)$ 
a. Piping (Cross Sectional Area $=60 \mathrm{ft}^{2}$ )

b. Mixing device

c. Flow controller

4. Hot gas recirculation $\left(1650 \mathrm{klb} / \mathrm{hr}\right.$ at $\left.325^{\circ} \mathrm{F}\right)$
a. Extraction port
b. Ducting to SA Fan (Cross Sectional Area $=185 \mathrm{ft}^{2}$ )
c. Flow controller
d. Air/gas switch junction

5. Cold gas recirculation $\left(900 \mathrm{klb} / \mathrm{hr}\right.$ at $\left.102^{\circ} \mathrm{F}\right)$
a. Extraction port
b. Ducting to PA Fan (Cross Sectional Area $=65 \mathrm{ft}^{2}$ )
c. Flow controller
d. Air/gas switch junction
e. Small reheat (i.e. $10^{\circ} \mathrm{F}$ ) by fluegas recuperator (using low-pressure water circulation) to avoid acid dew point

6. High pressure steam extraction $\left(18 \mathrm{klb} / \mathrm{hr}\right.$ at $\left.317 \mathrm{psia}, 816^{\circ} \mathrm{F}\right)$ for $\left.\mathrm{CPU} / \mathrm{ASU}\right]$
a. Steam extraction port
b. Piping
c. Flow control
d. De-superheater (including water spray and pump) to $425^{\circ} \mathrm{F}$ at $22 \mathrm{klb} / \mathrm{hr}$
e. Condensate return piping

7. Low pressure steam extraction $\left(13 \mathrm{klb} / \mathrm{hr}\right.$ at $\left.107 \mathrm{psia}, 552^{\circ} \mathrm{F}\right)$ for $\mathrm{CPU} / \mathrm{ASU}$
a. Steam extraction port
b. Piping
c. Flow control
d. De-superheater (including water spray and pump) to $342^{\circ} \mathrm{F}$ at $14 \mathrm{klb} / \mathrm{hr}$
e. Condensate return piping

8. CPU vent gas heater

$$
\begin{aligned}
& \text { Surface area }=3,560 \mathrm{ft}^{2} \\
& \text { Heat transfer }=10 \mathrm{Mbtu} / \mathrm{hr} \\
& \text { Inlet } / \text { outlet water temperature }=250^{\circ} \mathrm{F} / 525^{\circ} \mathrm{F} \\
& \text { Water flow rate }=34 \mathrm{klb} / \mathrm{hr} \\
& \text { LMTD }=290^{\circ} \mathrm{F}
\end{aligned}
$$

9. CPU vent gas heater circulation pump
a. Water flow rate $=34 \mathrm{klb} / \mathrm{hr}(70 \mathrm{gpm})$
b. Pressure increase $=100 \mathrm{psi}$
c. Power $=6 \mathrm{hp}$

10. Quenching tower

a. Booster fan 
b. Ducting

c. Water circulation pump

d. Acid water treatment

11. Flue gas duct to $\mathrm{CPU}\left(1108 \mathrm{klb} / \mathrm{hr}\right.$ at $\left.325^{\circ} \mathrm{F}\right)$
a. Extraction port
b. Ducting (Cross Sectional Area $=125 \mathrm{ft}^{2}$ )
c. Flow controller

12. FGD modification
a. Use oxygen instead of air for bubbling
b. $\mathrm{O}_{2}$ flow $=0.7 \mathrm{klb} / \mathrm{hr}$

13. Auxiliary air replacement by auxiliary $\mathrm{CO}_{2}$

a. Replace auxiliary air by $\mathrm{CO}_{2}$ for air purge systems and solid transport systems

b. $\mathrm{CO}_{2}$ flow $=1500 \mathrm{scfm}(11 \mathrm{klb} / \mathrm{hr})$ at $80 \mathrm{psig}$

14. Improved Boiler Sealing

a. Reduce air in-leakage by mechanical sealing (as is practical)

15. Enlarge cooling tower

a. Without ASU/CPU requirements, cooling tower increases by $20-25 \%$

16. DCS controller and instrumentation for oxyfuel operation, switch over from air, etc.

17. Flue gas cooler

\section{$\mathrm{O}_{2}$-Fired High Sulfur Fuel}

1. HRA lower economizer enlargement

Additional surface area $=22,250 \mathrm{ft}^{2}\left(\right.$ total surface area $\left.=72,350 \mathrm{ft}^{2}\right)$.

Total heat transfer $=171 \mathrm{Mbtu} / \mathrm{hr}$

Inlet $/$ Outlet Water temperature $=495^{\circ} \mathrm{F} / 545^{\circ} \mathrm{F}$ (total lower economizer)

Water flow rate $=2922 \mathrm{klb} / \mathrm{hr}$

$\mathrm{LMTD}=285^{\circ} \mathrm{F}$ (total lower economizer)

2. Low pressure economizer

Surface area $=108,150 \mathrm{ft}^{2}$ (Some tubes may require special coating to avoid flue gas acid corrosion)

Heat transfer $=107 \mathrm{Mbtu} / \mathrm{hr}$

Inlet $/$ outlet water temperature $=223^{\circ} \mathrm{F} / 268^{\circ} \mathrm{F}$

Water flow rate $=2349 \mathrm{klb} / \mathrm{hr}$

$\mathrm{LMTD}=130^{\circ} \mathrm{F}$

3. $\mathrm{O}_{2}$ distribution $\left(712 \mathrm{klb} / \mathrm{hr}\right.$ at $\left.120^{\circ} \mathrm{F}\right)$ 
a. Piping (Cross Sectional Area $=60 \mathrm{ft}^{2}$ )

b. Mixing device

c. Flow controller

4. Hot gas recirculation $\left(1350 \mathrm{klb} / \mathrm{hr}\right.$ at $\left.310^{\circ} \mathrm{F}\right)$
a. Extraction port
b. Ducting to SA Fan (Cross Sectional Area $=140 \mathrm{ft}^{2}$ )
c. Flow controller
d. Air/gas switch junction

5. Cold gas recirculation $\left(1480 \mathrm{klb} / \mathrm{hr}\right.$ at $\left.102^{\circ} \mathrm{F}\right)$
a. Extraction port
b. Ducting to PA Fan (Cross Sectional Area $=110 \mathrm{ft}^{2}$ )
c. Flow controller
d. Air/gas switch junction
e. Small reheat (i.e. $10^{\circ} \mathrm{F}$ ) by fluegas recuperator (using low-pressure water circulation) to avoid acid dew point

6. High pressure steam extraction $\left(18 \mathrm{klb} / \mathrm{hr}\right.$ at $\left.317 \mathrm{psia}, 816^{\circ} \mathrm{F}\right)$ for $\mathrm{CPU} / \mathrm{ASU}$
a. Steam extraction port
b. Piping
c. Flow control
d. De-superheater (including water spray and pump) to $425^{\circ} \mathrm{F}$ at $22 \mathrm{klb} / \mathrm{hr}$
e. Condensate return piping

7. Low pressure steam extraction $\left(13 \mathrm{klb} / \mathrm{hr}\right.$ at $\left.107 \mathrm{psia}, 552^{\circ} \mathrm{F}\right)$ for $\mathrm{CPU} / \mathrm{ASU}$
a. Steam extraction port
b. Piping
c. Flow control
d. De-superheater (including water spray and pump) to $342^{\circ} \mathrm{F}$ at $14 \mathrm{klb} / \mathrm{hr}$
e. Condensate return piping

8. CPU vent gas heater

$$
\begin{aligned}
& \text { Surface area }=3,560 \mathrm{ft}^{2} \\
& \text { Heat transfer }=10 \mathrm{Mbtu} / \mathrm{hr} \\
& \text { Inlet } / \text { outlet water temperature }=250^{\circ} \mathrm{F} / 525^{\circ} \mathrm{F} \\
& \text { Water flow rate }=34 \mathrm{klb} / \mathrm{hr} \\
& \text { LMTD }=290^{\circ} \mathrm{F}
\end{aligned}
$$

9. CPU vent gas heater circulation pump
a. Water flow rate $=34 \mathrm{klb} / \mathrm{hr}(70 \mathrm{gpm})$
b. Pressure increase $=100 \mathrm{psi}$
c. Power $=6 \mathrm{hp}$

10. Quenching tower
a. Booster fan
b. Ducting 
c. Water circulation pump

d. Acid water treatment

11. Flue gas duct to CPU $\left(970 \mathrm{klb} / \mathrm{hr}\right.$ at $\left.310^{\circ} \mathrm{F}\right)$

a. Extraction port

b. Ducting (Cross Sectional Area $=100 \mathrm{ft}^{2}$ )

c. Flow controller

12. FGD modification

a. Use oxygen instead of air for bubbling

13. Auxiliary air replacement by auxiliary $\mathrm{CO}_{2}$

a. Replace auxiliary air by $\mathrm{CO}_{2}$ for air purge systems and solid transport systems

b. $\mathrm{CO}_{2}$ flow $=1500 \mathrm{scfm}(11 \mathrm{klb} / \mathrm{hr})$ at $80 \mathrm{psig}$

14. Improved Boiler Sealing

a. Reduce air in-leakage by mechanical sealing (as is practical)

15. Enlarge cooling tower

a. Without ASU/CPU requirements, cooling tower increases by $20-25 \%$

16. DCS controller and instrumentation for oxyfuel operation, switch over from air, etc.

17. Primary gas heater (tubular, gas-to-gas)

Surface area $=45,240 \mathrm{ft}^{2}$

Heat transfer $=26 \mathrm{Mbtu} / \mathrm{hr}$

Inlet $/$ outlet primary gas temperature $=102^{\circ} \mathrm{F} / 253^{\circ} \mathrm{F}$

Primary air flow rate $=775 \mathrm{klb} / \mathrm{hr}$

$\mathrm{LMTD}=135^{\circ} \mathrm{F}$

18. Flue gas cooler

\section{Constraints and Limitations}

Note that for the design proposed herein, all limitations have been checked and are acceptable at full load conditions.

1. ID fan surge limit

The maximum quantity of flue gas recirculation is limited by the existing ID fan capacity (i.e. surge limit). Above this limit the furnace pressure is not controllable. For example, this limit may be reached when flue gas recycle is above $75-80 \%$.

2. Superheater attemperators 
The minimum quantity of flue gas recirculation is limited by the attemperator design. Below this limit the attemperator flow reduces to zero and the superheat temperature is not controllable. This is produced by too much heat absorption and steam generation in the furnace resulting in HRA flue gas energy, which is insufficient to reach the design outlet steam temperature. For example, this limit may be reached when flue gas recycle is below $60-65 \%$.

The maximum quantity of flue gas recirculation is limited by the maximum water spray capacity of the attemperator design. Above this limit the superheat temperature is not controllable. For example, this limit may be reached when flue gas recycle is above 75$80 \%$.

3. Tube metal temperatures

The quantity of flue gas recirculation is limited by the design tube metal temperature margins. As the recycled flue gas flow rate is reduced, furnace waterwall temperatures increase and HRA tube metal temperatures decrease. As recycled flue gas flow rate is increased, furnace waterwall temperatures decrease and HRA tube metal temperatures increase.

4. Burner design

Burner design operational limits should be checked to determine limitations on flue gas recirculation conditions at full and part loads.

5. Cold gas recirculation SOx removal

SOx should be removed as much as possible from cold gas (primary gas) recirculation to avoid acid dew point corrosion in mill and downstream piping.

6. Steam turbine

The shutting off of low pressure feedwater heater(s) will increase flow to the low pressure turbine sections. Turbine design should be checked to determine if this can be accommodated. Note that in the design proposed herein, low pressure steam flow increases by $4 \%$. 


\section{Oxyfuel Incremental Equipment Cost Estimate}

\section{$\mathrm{O}_{2}$-Fired Low Sulfur Fuel}

A conceptual level cost estimate was performed for the incremental equipment and installation cost of the oxyfuel retrofit in the boiler island and steam system (covering Foster Wheeler's scope of the plant simulation) for the reference $460 \mathrm{MW}$ (gross) plant firing PRB low sulfur fuel. The estimate is summarized in Table 13.

\section{Table 13 - Low Sulfur Fuel $\mathbf{O}_{2}$-Fired Retrofit Incremental Cost Estimate}

\begin{tabular}{|l|r|}
\cline { 2 - 2 } \multicolumn{1}{c|}{} & \multicolumn{1}{c|}{ M \$ } \\
\hline Heat Exchangers & 35.95 \\
Piping and ducting & 37.15 \\
Boiler Sealing & 7.85 \\
\hline Total & 80.95 \\
\hline
\end{tabular}

Details of the estimate assumptions and methodology are presented below.

1. HRA lower economizer enlargement

The heating surface of the lower economizer located below the convection pass Heat Recovery Area (HRA) was increased 22,250 $\mathrm{ft}^{2}$, for a total lower economizer surface area of $72,350 \mathrm{ft}^{2}$. The additional heating surface is comprised of 2" OD carbon steel tubes.

It is typical design practice to include space for additional loops of heating surface in new unit designs. This practice allows for the addition of heating surface at a later date to achieve performance guarantees or to provide fuel switching flexibility. The original design of the reference unit for this study included space for additional loops of economizer surface. Therefore the additional surface noted above was added without need for modifications to the economizer inlet/outlet headers, boiler casing or boiler support steel.

2. Low pressure economizer

Low pressure economizer heating surface area of $144,200 \mathrm{ft}^{2}$ was added in the flues downstream of the regenerative air heater.

This additional surface was not considered in the original design of the unit. Therefore, in addition to the 2" OD carbon steel tubes, inlet and outlet headers, transfer piping to / from the new heating surface to the feedwater heater bay, plate casing, sootblowers and support steel were added. Valves for control and isolation of the water flow to the LPEC are included. 
Due to the low temperature of the flue gas at this location, this LPEC does not need to be bypassed when not in service. Therefore, no bypass ducts or dampers have been considered.

3. $\mathrm{O}_{2}$ distribution $\left(725 \mathrm{klb} / \mathrm{hr}\right.$ at $\left.120^{\circ} \mathrm{F}\right)$

$\mathrm{O}_{2}$ supply (with flow control) from the ASU to the boiler area is by others. $\mathrm{O}_{2}$ mixing with recirculated flue gas and its distribution within the boiler area has been considered by the boiler supplier.

An $\mathrm{O}_{2}$ injection grid with a mixing device was added upstream of the FD fans. The proposed equipment is similar to the injection grids and mixing devices employed for SCR systems. However, the components and casing in the mixing area are stainless steel material for safety considerations. Costs include additional ducting and support steel.

4. Hot gas recirculation $\left(1650 \mathrm{klb} / \mathrm{hr}\right.$ at $\left.325^{\circ} \mathrm{F}\right)$

Ducts of $185 \mathrm{ft}^{2}$ cross sectional area for recirculation of hot flue gas $\left(325^{\circ} \mathrm{F}\right)$ from upstream of a wet FGD system to the FD fan inlets have been added.

The ducts are of carbon steel material. Costs include the dampers for air/gas proportioning, turning vanes, expansion joints and support steel.

5. Cold gas recirculation $\left(900 \mathrm{klb} / \mathrm{hr}\right.$ at $\left.102^{\circ} \mathrm{F}\right)$

Ducts of $80 \mathrm{ft}^{2}$ cross sectional area for recirculation of cold flue gas $\left(102^{\circ} \mathrm{F}\right)$ from downstream of the FGD system to the PA fans inlets have been added.

The ducts are of carbon steel material. Costs include the dampers for air/gas proportioning, turning vanes, expansion joints and support steel. In addition, small amount of reheat (i.e. $10^{\circ} \mathrm{F}$ ) by fluegas recuperator (using low-pressure water circulation) was included to avoid acid dew point concerns in the mill system.

6. High pressure steam extraction $\left(18 \mathrm{klb} / \mathrm{hr}\right.$ at $317 \mathrm{psia}, 816^{\circ} \mathrm{F}$ at turbine $)$ for $\mathrm{CPU} / \mathrm{ASU}$

High pressure steam supply piping from the steam turbine or power piping to ASU and CPU including flow control valves, desuperheating station, lagging/insulation and pipe supports have been added.

High pressure steam condensate return piping from the ASU and CPU to the condenser hotwell including flow control valves and pipe supports have been added.

Steam supply and return piping inside the ASU and CPU is by others.

7. Low pressure steam extraction $\left(13 \mathrm{klb} / \mathrm{hr}\right.$ at $107 \mathrm{psia}, 552^{\circ} \mathrm{F}$ at turbine $)$ for CPU/ASU 
Low pressure steam supply piping from the steam turbine or power piping to ASU (located next to the boiler) and CPU (located to the rear of the boiler, by the stack) including flow control valves, desuperheating station and pipe supports have been added.

Low pressure steam condensate return piping from the ASU and CPU to the condenser hotwell including flow control valves, lagging/insulation and pipe supports have been added.

Steam supply and return piping inside the ASU and CPU is by others.

8. CPU vent gas heater

A gas over tube bundle type heat exchanger with $3,560 \mathrm{ft}^{2}$ of heat transfer surface has been added. Casing and steel support is included.

9. CPU vent gas heater circulation pump

a. Water flow rate $=34 \mathrm{klb} / \mathrm{hr}(70 \mathrm{gpm})$

b. Pressure increase $=100 \mathrm{psi}$

c. Power $=6 \mathrm{hp}$

BY OTHERS (Not included in estimate).

10. Quenching tower
a. Booster fan
b. Ducting
c. Water circulation pump
d. Acid water treatment

BY OTHERS (Not included in estimate).

11. Flue gas duct to $\mathrm{CPU}\left(1108 \mathrm{klb} / \mathrm{hr}\right.$ at $\left.325^{\circ} \mathrm{F}\right)$

Gas ducts of $125 \mathrm{ft}^{2}$ cross sectional area from quenching tower to CPU have been added. These ducts are sized for $1,108,000 \mathrm{lbs} /$ hour of $\mathrm{CO}_{2}$ gas at $325^{\circ} \mathrm{F}$.

The ducts are of carbon steel material. Costs include the dampers for air/gas proportioning, turning vanes, expansion joints and support steel.

12. FGD modification

a. Use oxygen instead of air for bubbling

b. $\mathrm{O}_{2}$ flow $=0.7 \mathrm{klb} / \mathrm{hr}$

BY OTHERS (Not included in estimate).

13. Auxiliary air replacement by auxiliary $\mathrm{CO}_{2}$ 
Piping as required to replace auxiliary air with $\mathrm{CO}_{2}$ for air purge systems and solid transport systems has been added.

\section{Improved Boiler Sealing}

Improved seals at all locations in the boiler and flues/ducts have been added. Additional sealing of manways and observation ports by use of aspirating air type seals ( using $\mathrm{CO}_{2}$ instead of air) and a penthouse pressurization fan system (again using $\mathrm{CO}_{2}$ instead of air) have been added. $\mathrm{CO}_{2}$ piping and ducting have been added as required.

15. Enlarge cooling tower

a. Without ASU/CPU requirements, cooling tower increases by $20-25 \%$

BY OTHERS (Not included in estimate).

16. DCS controller and instrumentation for oxyfuel operation, switch over from air, etc.

BY OTHERS (Not included in estimate).

17. Flue gas cooler

BY OTHERS (Not included in estimate).

NOTE: A plot plan and sectional side view drawings of the reference unit were used to estimate lengths of runs of pipe, flues and ducts. Tie-in points were estimated based on the process requirements. However, due to the complexity of retrofit work, the details of the tie-ins to the reference unit have not been fully assessed. 


\section{$\mathrm{O}_{2}$-Fired High Sulfur Fuel}

A conceptual level cost estimate was performed for the incremental equipment and installation cost of the oxyfuel retrofit in the boiler island and steam system (covering Foster Wheeler's scope of the plant simulation) for the reference $460 \mathrm{MW}$ (gross) plant firing bituminous high sulfur fuel. The estimate is summarized in Table 14.

Table 14 - High Sulfur Fuel $\mathrm{O}_{2}$-Fired Retrofit Incremental Cost Estimate

\begin{tabular}{|l|r|}
\cline { 2 - 2 } \multicolumn{1}{c|}{} & \multicolumn{1}{c|}{$\mathrm{M} \$$} \\
\hline Heat Exchangers & 33.87 \\
Piping and ducting & 42.70 \\
Boiler Sealing & 7.89 \\
\hline Total & 84.46 \\
\hline
\end{tabular}

Details of the estimate assumptions and methodology are presented below.

1. HRA lower economizer enlargement

The heating surface of the lower economizer located below the convection pass Heat Recovery Area (HRA) was increased 22,250 $\mathrm{ft}^{2}$, for a total lower economizer surface area of $72,350 \mathrm{ft}^{2}$. The additional heating surface is comprised of 2" OD carbon steel tubes.

It is typical design practice to include space for additional loops of heating surface in new unit designs. This practice allows for the addition of heating surface at a later date to achieve performance guarantees or to provide fuel switching flexibility. The original design of the reference unit for this study included space for additional loops of economizer surface. Therefore the additional surface noted above was added without need for modifications to the economizer inlet/outlet headers, boiler casing or boiler support steel.

2. Low pressure economizer

Low pressure economizer heating surface area of $108,150 \mathrm{ft}^{2}$ was added in the flues downstream of the regenerative air heater.

This additional surface was not considered in the original design of the unit. Therefore, in addition to the 2" OD carbon steel tubes, inlet and outlet headers, transfer piping to / from the new heating surface to the feedwater heater bay, plate casing, sootblowers and support steel were added. Valves for control and isolation of the water flow to the LPEC are included. 
Due to the low temperature of the flue gas at this location, this LPEC does not need to be bypassed when not in service. Therefore, no bypass ducts or dampers have been considered.

3. $\mathrm{O}_{2}$ distribution $\left(712 \mathrm{klb} / \mathrm{hr}\right.$ at $\left.120^{\circ} \mathrm{F}\right)$

$\mathrm{O}_{2}$ supply (with flow control) from the ASU to the boiler area is by others. $\mathrm{O}_{2}$ mixing with recirculated flue gas and its distribution within the boiler area has been considered by the boiler supplier.

An $\mathrm{O}_{2}$ injection grid with a mixing device was added upstream of the FD fans. The proposed equipment is similar to the injection grids and mixing devices employed for SCR systems. However, the components and casing in the mixing area are stainless steel material for safety considerations. Costs include additional ducting and support steel.

4. Hot gas recirculation $\left(1350 \mathrm{klb} / \mathrm{hr}\right.$ at $\left.325^{\circ} \mathrm{F}\right)$

Ducts of $140 \mathrm{ft}^{2}$ cross sectional area for recirculation of hot flue gas $\left(325^{\circ} \mathrm{F}\right)$ from upstream of a wet FGD system to the FD fan inlets have been added.

The ducts are of carbon steel material. Costs include the dampers for air/gas proportioning, turning vanes, expansion joints and support steel.

5. Cold gas recirculation $\left(1480 \mathrm{klb} / \mathrm{hr}\right.$ at $\left.102^{\circ} \mathrm{F}\right)$

Ducts of $110 \mathrm{ft}^{2}$ cross sectional area for recirculation of cold flue gas $\left(102^{\circ} \mathrm{F}\right)$ from downstream of the FGD system to the PA fans inlets have been added.

The ducts are of carbon steel material. Costs include the dampers for air/gas proportioning, turning vanes, expansion joints and support steel. In addition, small amount of reheat (i.e. $10^{\circ} \mathrm{F}$ ) by fluegas recuperator (using low-pressure water circulation) was included to avoid acid dew point concerns in the mill system.

6. High pressure steam extraction $\left(18 \mathrm{klb} / \mathrm{hr}\right.$ at $317 \mathrm{psia}, 816^{\circ} \mathrm{F}$ at turbine $)$ for $\mathrm{CPU} / \mathrm{ASU}$

High pressure steam supply piping from the steam turbine to ASU and CPU including flow control valves, desuperheating station, lagging/insulation and pipe supports have been added.

High pressure steam condensate return piping from the ASU and CPU to the condenser hotwell including flow control valves and pipe supports have been added.

Steam supply and return piping inside the ASU and CPU is by others.

7. Low pressure steam extraction $\left(13 \mathrm{klb} / \mathrm{hr}\right.$ at $107 \mathrm{psia}, 552^{\circ} \mathrm{F}$ at turbine $)$ for CPU/ASU 
Low pressure steam supply piping from the steam turbine to ASU (located next to the boiler) and CPU (located to the rear of the boiler, by the stack) including flow control valves, desuperheating station and pipe supports have been added.

Low pressure steam condensate return piping from the ASU and CPU to the condenser hotwell including flow control valves, lagging/insulation and pipe supports have been added.

Steam supply and return piping inside the ASU and CPU is by others.

8. CPU vent gas heater

A gas over tube bundle type heat exchanger with $3,560 \mathrm{ft}^{2}$ of heat transfer surface has been added. Casing and steel support is included.

9. CPU vent gas heater circulation pump
a. Water flow rate $=34 \mathrm{klb} / \mathrm{hr}(70 \mathrm{gpm})$
b. Pressure increase $=100 \mathrm{psi}$
c. Power $=6 \mathrm{hp}$

BY OTHERS (Not included in estimate).

10. Quenching tower
a. Booster fan
b. Ducting
c. Water circulation pump
d. Acid water treatment

BY OTHERS (Not included in estimate).

11. Flue gas duct to $\mathrm{CPU}\left(970 \mathrm{klb} / \mathrm{hr}\right.$ at $\left.325^{\circ} \mathrm{F}\right)$

Gas ducts of $100 \mathrm{ft}^{2}$ cross sectional area from quenching tower to CPU have been added. These ducts are sized for $970,000 \mathrm{lbs} /$ hour of $\mathrm{CO}_{2}$ gas at $325^{\circ} \mathrm{F}$.

The ducts are of carbon steel material. Costs include the dampers for air/gas proportioning, turning vanes, expansion joints and support steel.

12. FGD modification

a. Use oxygen instead of air for bubbling

BY OTHERS (Not included in estimate).

13. Auxiliary air replacement by auxiliary $\mathrm{CO}_{2}$ 
Piping as required to replace auxiliary air with $\mathrm{CO}_{2}$ for air purge systems and solid transport systems has been added.

\section{Improved Boiler Sealing}

Improved seals at all locations in the boiler and flues/ducts have been added. Additional sealing of manways and observation ports by use of aspirating air type seals ( using $\mathrm{CO}_{2}$ instead of air) and a penthouse pressurization fan system (again using $\mathrm{CO}_{2}$ instead of air) have been added. $\mathrm{CO}_{2}$ piping and ducting have been added as required.

15. Enlarge cooling tower

a. Without ASU/CPU requirements, cooling tower increases by $20-25 \%$

BY OTHERS (Not included in estimate).

16. DCS controller and instrumentation for oxyfuel operation, switch over from air, etc.

BY OTHERS (Not included in estimate).

17. Primary Gas Heater (tubular, gas-to-gas) [PAHA/PAHB]

A tubular gas-to-gas heat exchanger with $45,240 \mathrm{ft}^{2}$ of heat transfer surface has been added. Casing and steel support is included.

18. Flue gas cooler

BY OTHERS (Not included in estimate).

NOTE: A plot plan and sectional side view drawings of the reference unit were used to estimate lengths of runs of pipe, flues and ducts. Tie-in points were estimated based on the process requirements. However, due to the complexity of retrofit work, the details of the tie-ins to the reference unit have not been fully assessed. 


\section{Conclusions}

A reference air-fired plant burning low sulfur PRB and high sulfur bituminous fuel was simulated. The reference air-fired plant has a boiler efficiency (PRB/Bituminous) of $86.7 \% / 89.3 \%$ and a plant net efficiency of $35.8 / 36.7 \%$.

The plant design was modified to accommodate oxyfuel firing. The flue gas recirculation flow to the boiler is $68 \%$ for PRB and $72 \%$ for bituminous. Maximum increase in tube wall temperature is less than $10^{\circ} \mathrm{F}$. At the furnace outlet, compared to air-firing, NOx mole fraction is about the same for PRB-firing and 2.5 times for bituminous-firing and $\mathrm{CO}$ mole fraction is approximately double.

Retrofitting of existing power plants for oxyfuel combustion is prudent for large (> $300 \mathrm{MW}$ ) high efficiency coal plants (subcritical or supercritical). Alternatively, retrofitting is not attractive for old, lower efficiency, smaller units. For these plants, rebuilding or repowering is more suitable.

By proper selection of the quantity of flue gas recycle flow, the boiler (furnace, HRA, air-heater, etc.) can be completely reused in oxy-fuel mode. Boiler retrofit challenges mostly center on the flue gas recycle and the oxygen distribution systems. These challenges include physical routing of ducts and pipes, selection of materials to avoid corrosion, and proper mixing of gases. Another challenge is the development of a control system and control logic for power plant start-up, shutdown, and switchover from air-firing to oxyfuel firing. An additional area for development is improved sealing of the boiler to increase the effectiveness of the $\mathrm{CO}_{2}$ capture. Overall power plant retrofit constraints include proximity to geologic sequestration, space availability (especially for ASU and CPU), and access to additional water supply for increased cooling load.

For the reference plant presented herein there appears to be no major obstacles to oxyfuel retrofit; however, specific constraints and limitations must be reevaluated by a detailed design.

Areas requiring further study include: 1) Furnace radiation heat transfer coefficients in oxy-firing vs. air-firing, 2) Burner design modifications for $\mathrm{O}_{2}$-firing and 3) Retrofit costs vs. clean slate costs. 


\section{List of Acronyms and Abbreviations}

\begin{tabular}{ll} 
ASU & Air Separation Unit \\
CFD & Computational fluid dynamics \\
CPU & CO $_{2}$ Processing Unit \\
Div & Division \\
DOE & Department of Energy \\
Econ & Economizer \\
FD & Forced draft \\
FEGT & Furnace exit gas temperature \\
FGD & Flue Gas Desulfurization \\
FW & Foster Wheeler, feedwater \\
FW-FIRE & Fossil fuel, Water-walled Furnace Integrated Reaction and Emission Simulation \\
HHV & Higher Heating Value \\
HRA & Heat recovery area \\
ID & Induced draft \\
LMTD & Log mean temperature difference \\
LPECO & Low pressure economizer \\
NETL & National Energy Technology Laboratory \\
NOx & Nitrogen Oxides \\
OD & Outside diameter \\
OFA & Over-fired air \\
PA & Primary Air \\
PC & Pulverized Coal \\
PM & Particulate Matter \\
PRB & Powder River Bain \\
RH & Reheater \\
SA & Secondary Air \\
SCR & Selective Catalytic Reactor \\
SH & Superheater \\
SOx & Sulfur Oxides \\
VOC & Volatile Organic Compound \\
& \\
\hline &
\end{tabular}

